\title{
The Key Differences between Human Papillomavirus-Positive and -Negative Head and Neck Cancers: Biological and Clinical Implications
}

\author{
Steven F. Powell ${ }^{1,+}{ }^{+}$Lexi $\mathrm{Vu}^{2,+} \mathbb{(}$, William C. Spanos ${ }^{1, *}$ and Dohun Pyeon ${ }^{2, *}$ \\ 1 Cancer Biology and Immunotherapies Group, Sanford Research, Sioux Falls, SD 57104, USA; \\ steven.powell@sanfordhealth.org \\ 2 Department of Microbiology and Molecular Genetics, Michigan State University, \\ East Lansing, MI 48824, USA; vulexi@msu.edu \\ * Correspondence: william.spanos@sanfordhealth.org (W.C.S.); dpyeon@msu.edu (D.P.) \\ + These authors contributed equally to this work.
}

check for

updates

Citation: Powell, S.F.; Vu, L.; Spanos, W.C.; Pyeon, D. The Key Differences between Human PapillomavirusPositive and -Negative Head and Neck Cancers: Biological and Clinical Implications. Cancers 2021, 13, 5206. https://doi.org/10.3390/

cancers13205206

Academic Editor: David Wong

Received: 13 September 2021

Accepted: 13 October 2021

Published: 17 October 2021

Publisher's Note: MDPI stays neutral with regard to jurisdictional claims in published maps and institutional affiliations.

Copyright: (c) 2021 by the authors. Licensee MDPI, Basel, Switzerland. This article is an open access article distributed under the terms and conditions of the Creative Commons Attribution (CC BY) license (https:// creativecommons.org/licenses/by/ $4.0 /)$.
Simple Summary: Head and neck cancer (HNC) is the sixth most common cancer, causing almost half a million deaths worldwide every year. The two subtypes of HNC are distinctly associated with smoking/drinking and/or human papillomavirus (HPV) infection. While the incidence of non-viral HNC is decreasing, HPV-positive HNC incidence has dramatically increased in the last few decades. Accumulating evidence from numerous studies shows molecular and clinical differences in mutations, gene expression regulation, treatment responses, and patient survival rates between HPV-positive and HPV-negative HNC. Here, we discuss the current status of HNC research and clinical approaches and suggest unanswered questions and future directions.

Abstract: Head and neck squamous cell carcinoma (HNSCC) is a unique malignancy associated with two distinct risk factors: exposure to typical carcinogens and infection of human papillomavirus (HPV). HPV encodes the potent oncoproteins E6 and E7, which bypass many important oncogenic processes and result in cancer development. In contrast, HPV-negative HNSCC is developed through multiple mutations in diverse oncogenic driver genes. While the risk factors associated with HPV-positive and HPV-negative HNSCCs are discrete, HNSCC patients still show highly complex molecular signatures, immune infiltrations, and treatment responses even within the same anatomical subtypes. Here, we summarize the current understanding of biological mechanisms, treatment approaches, and clinical outcomes in comparison between HPV-positive and -negative HNSCCs.

Keywords: head and neck cancer; head and neck squamous cell carcinoma; human papillomavirus; treatment; clinical outcome; tumor microenvironment; molecular carcinogenesis; microbiome; surgery; de-escalation strategies; clinical trials

\section{Introduction}

Head and neck squamous cell carcinomas (HNSCC) comprise squamous cell carcinoma of the oral cavity, nasal cavity, pharynx (oropharynx and hypopharynx), larynx, and tongue. Combining them all, more than 68,000 cases of HNSCC are annually reported, accounting for $\sim 4 \%$ of all cancers in the United States [1]. Unlike most other solid cancers, HNSCCs arise from broad anatomical sites where cell type compositions are largely diverse with high heterogeneity. While smoking and drinking are well known as main risk factors, a significant number of HNSCCs in the oropharynx are also associated with infection of viruses such as human papillomavirus (HPV) [2-4].

The molecular and clinical differences of HPV-positive (HPV+) and HPV-negative (HPV-) HNSCCs are substantial; and they are now largely considered as two distinct cancers despite their histological similarities $[2,5,6]$. HPV+ HNSCC is caused by the various 
oncogenic functions of high-risk HPV E6 and E7, which may efficiently compensate for common oncogenic driver mutations that lead to HNSCC carcinogenesis (Figure 1) [2,5,7]. Indeed, the Cancer Genome Atlas (TCGA) data demonstrate significantly higher mutation loads in HPV - HNSCC than in HPV+ HNSCC [8-10].

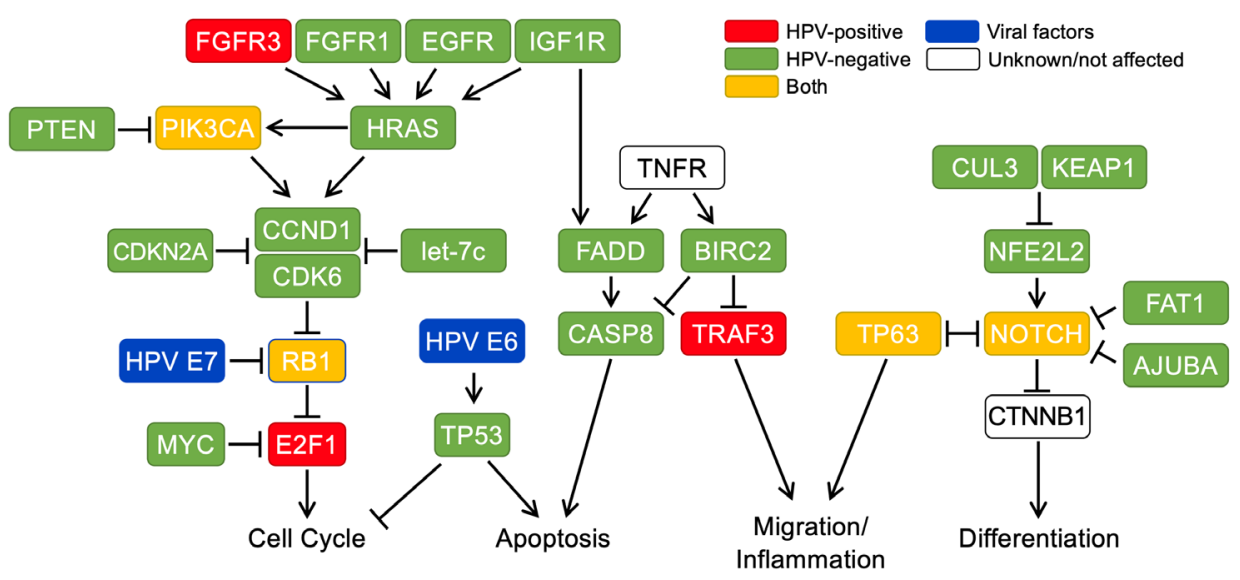

Figure 1. An overview of the key factors and pathways with genome mutations and molecular dysregulations in HPV+ and HPV- HNSCCs [7,10]. Genome mutations and alterations mainly found in HPV+, HPV-, and both HNSCCs are indicated with red, green, and yellow boxes, respectively. The HPV oncogenes E6 and E7 are shown as blue boxes, and unknown or unaffected genes are shown as white boxes. FGFR3, fibroblast growth factor receptor 3; FGFR1, fibroblast growth factor receptor 1; EGFR, epidermal growth factor receptor; IGF1R, insulin like growth factor 1 receptor; PTEN, phosphatase and tensin homolog; PIK3CA, phosphatidylinositol-4,5-bisphosphate 3-kinase catalytic subunit alpha; HRAS, Hras proto-oncogene, GTPase; CCND1, cyclin D1; CDK6, cyclin dependent kinase 6; CDKN2A, cyclin dependent kinase inhibitor 2A; let-7c, microRNA let-7c; RB1, RB transcriptional corepressor 1; MYC, MYC proto-oncogene, BHLH transcription factor; E2F1, E2F transcription factor 1; TP53, tumor protein P53; TNFR, tumor necrosis factor receptor; FADD, fas associated via death domain; CASP8, caspase 8; TRAF3, tumor necrosis factor receptor associated factor 3; CUL3, cullin 3; KEAP1, kelch like ECH associated protein 1; NFE2L2, nuclear factor, erythroid 2 like 2; TP63, tumor protein P63; NOTCH, notch receptor; FAT1, FAT atypical cadherin 1; AJUBA, ajuba LIM protein; CTNNB1, catenin beta 1 .

The incidence of HNSCC in the oropharynx associated with HPV infection has significantly increased in the last few decades $[11,12]$. The overall incidence of HPV- HNSCC has decreased, probably due to the reduction in smoking populations in the United States [13]. Several recent studies have shown that the oncogenic mechanisms of HNSCCs, particularly between HPV+ and HPV - HNSCCs, are unique and extremely diverse [5,8]. HPV+ HNSCC patients show significantly better survival rates following the standard chemoradiation therapy (CRT) compared to HPV- HNSCC patients [14-16]. However, despite these improved outcomes, those with HPV+ HNSCC still develop recurrent/metastatic $(\mathrm{R} / \mathrm{M})$ disease as the high-risk subgroup of HPV+ HNSCC. There is little insight to clearly explain the mechanisms that lead to the differential response to CRT and patient survival. Although it is under intense focus, limited tools are available to distinguish those within the high-risk subgroup of HPV+ HNSCC.

This high diversity and heterogeneity of HNSCC make it arduous to identify key targets to develop effective cancer therapeutics and treatment strategies. As a brainstorming effort to overcome these hurdles, here we summarize the current state of our understanding and clinical observations to inform future directions in HNSCC research.

\section{Molecular Carcinogenesis Is Distinct between HPV+ and HPV - HNSCCs}

The genetic landscape of HNSCC carcinogenesis shows two distinct oncogenic pathways, driven by either chemical carcinogens or HPV infection [2]. Smoking and alcohol 
use have long been characterized as the major risk factors for developing HNSCC, independent of HPV infection [17-19]. The carcinogenic nitrosamines formed from tobacco and acetaldehyde from alcohol can be metabolically activated and covalently bound to DNA, forming DNA adducts that disrupt the DNA double helix $[20,21]$. Persistent DNA adducts lead to hypermutations and chromosomal instability, some of which accidentally dysregulate crucial cellular mechanisms and pathways in cell homeostasis, resulting in cancer progression $[22,23]$. This effect may be exacerbated by alcohol, as it can act as a solvent to introduce tobacco-related carcinogens into the mucosa of the head and neck region $[24,25]$. Furthermore, alcohol induces the enzyme encoded by cytochrome p450 2E1 (CYP2E1), an activator of nitrosamine metabolism [26]. As a result, alcohol and tobacco act synergistically to promote HNSCC carcinogenesis [19,27]. Beyond alcohol and tobacco, other topical exposures, such as betel nuts, are known to be linked to HNSCC by generating nitroso-derivatives similar to tobacco smoking from alkaloid ingredients [28,29].

In many cases, tobacco is sufficient to exert carcinogenic effects independent of alcohol use. The risk of the development of HNSCC with tobacco alone is higher than alcohol alone. However, the combination of alcohol and tobacco has a multiplicative associated risk [30]. Studies have shown that the reactive oxygen and nitrogen species found in cigarette smoke (CS) are known to lead to oxidative stress and activation of proinflammatory pathways in lung fibroblasts [31-33]. Recently, it was shown that fibroblasts exposed to CS have the potential to alter the tumor microenvironment (TME) in HNSCC through similar mechanisms as the lung fibroblasts [34,35]. CS induced oxidative stress and expression of the hypoxia responsive gene monocarboxylate transporter 4 (MCT4) in fibroblasts in vitro [36]. Tumors generated from co-injection with CS-exposed fibroblasts showed a marked increase in the macrophage markers CD45 and CD68 in vivo [37]. CS is also well known to induce immune suppression by modulating various immune mechanisms in other cancers [38-40]. Notably, increased macrophages in the TME are a characteristic of HNSCC associated with smoking and immune suppression [37,41,42]. This suggests that smoking dysregulates antitumor immune mechanisms that are distinct from virusmediated immune suppression [43]. The differential immune dysregulations are further discussed below.

An emerging mechanism of tobacco-induced carcinogenesis is through altered microRNA (miRNA) expression [44,45]. miRNAs are small, non-coding RNAs that play a role in posttranscriptional gene regulation and translation inhibition [46]. Disruption of miRNA regulation by tobacco exposure may lead to changes in major cellular signaling pathways and metabolic processes. Indeed, increased production of nicotine-derived nitrosamine ketone (NNK), a carcinogenic component of tobacco, in HNSCC cells upregulates expression of several oncogenic miRNAs, including miR-21, miR-155, and miR-944, while downregulating expression of the tumor suppressor miRNA miR-422a in HNSCC cells in in vitro culture [47,48]. The upregulation of miR-944 expression in HNSCC induces the secretion of proinflammatory cytokines and activates signal transducer and activator of transcription 3 (STAT3), contributing to tumorigenesis [48]. Using mouse and rat models of tobaccoassociated HNSCC, a recent study has shown that the family of miR-30 is significantly downregulated in tumors compared to normal tongue tissue [49]. The cellular targets of the miR-30 family of microRNAs (miRNAs) include messenger RNAs (mRNAs) involved in cell proliferation, differentiation, adhesion, and invasion [50,51]. This downregulation of the miR-30 family has also been observed in the analyses of HNSCC cell lines and TCGA HNSCC datasets [49,52]. However, miRNA targets are context-dependent, many are still unknown including the contributions of HPV, and cell lines and animal models may differ from patient samples. Thus, further studies are needed to establish a causal link between tobacco induced HNSCC development and miRNA alterations.

Conversely, the genetic alterations observed in HPV-driven HNSCCs are predominantly caused by the viral oncogenes E6 and E7 following persistent infection of high-risk HPV, such as HPV16 and HPV18. The HPV genome is also frequently integrated into the host chromosome, occasionally forming concatemers of multiple HPV E6/E7 seg- 
ments $[53,54]$. The linearization of the HPV genome creates a breakpoint in the early gene E2, the only transcription factor encoded by the HPV genome [55,56]. While HPV E2 functions as a negative regulator of early viral gene expression, including E6 and E7, integration of the HPV genome frequently truncates E2, preventing transcriptional repression of the E6 and E7 oncogenes [57,58]. High-risk HPV E6 and E7 dysregulate various cellular pathways, including inactivation of the tumor suppressors p53 and pRB, respectively [59]. Furthermore, the varying integration sites have been shown to alter gene expression to promote cancer progression. For example, it has been found that HPV DNA insertion into the RAD51 homolog $2(R A D 51 B)$ gene, which is a core component of the DNA double-strand break repair, promotes the formation of alternative transcripts, generating a non-functional RAD51 protein $[58,60]$. In addition to the E6/E7, a recent study suggests an alternative oncogenic mechanism of the E2/E4/E5 subtype of HPV+ HNSCC containing episomal $\mathrm{HPV}$, which shows fibroblast growth factor receptor (FGFR) activation and p53-dependent cell proliferation [61].

The previous TCGA studies have revealed that HPV+ HNSCC shows significantly lower rates of allelic loss and genetic mutations compared to HPV- HNSCC [8,9]. The coding sequences of several tumor suppressors in HPV- HNSCC contain driver mutations that are not observed in HPV+ HNSCC (Figure 1). One of the most striking contrasts is p53, which is mutated in the vast majority of HPV - HNSCC, but rarely in HPV+ HNSCC $[8,62]$. In addition, a comparison of HPV+ and HPV - tumor samples from patients of a similar age and tumor site using microarray-based comparative genomic hybridization (maCGH) showed a significantly higher number of chromosomal alterations in HPVtumors compared to HPV+ tumors [63,64]. Four chromosomal regions, the smallest of which spanned four megabases, were found to be significantly altered in HPV - tumors, whereas no change or a change in the opposite direction were found in HPV+ tumors [63]. In contrast, distinct chromosome aberrations are associated with viral integration sites in HPV+ HNSCC, contributing to cancer progression $[65,66]$. Taken together, it is likely that expression of the viral oncogenes E6 and E7 is sufficient to inactivate many of the critical tumor suppressor pathways, promoting carcinogenesis without generating somatic mutations in tumor suppressor genes.

In addition to the dysregulation of the common oncogenic pathways, there are gene expression distinctions between HPV+ and HPV - HNSCCs. Our previous studies of global gene expression analysis revealed that expression of cell cycle-related genes is highly expansive in HPV+ tumors and dissimilar to HPV - HNSCC [5,67]. These unique gene expression patterns are functionally associated with the significantly higher cell proliferation rate of HPV+ tumor cells compared to HPV - tumor cells. These findings imply that HPV+ HNSCC is a cancer type that is distinct from HPV- HNSCC, and accordingly requires different treatment strategies.

\section{Differential Immune Responses between HPV+ and HPV- HNSCCs}

It is expected that there are fundamental differences in immune responses between $\mathrm{HPV}+$ and HPV - cancers, as HPV+ HNSCC expresses viral proteins as foreign antigens, in addition to other neoantigens created by viral integration and mutagenesis induced by the viral restriction factor APOBEC3 [68-70]. In contrast, HPV- HNSCC lacks foreign antigens, rather, they are generated from extensive random mutations or overexpressed cellular genes [16,71]. Accordingly, it is generally accepted that HPV+ HNSCC shows more robust antitumor immune responses compared to HPV - HNSCC. Nevertheless, recent immunotherapy trials have not found any clear benefits of using immune checkpoint inhibitors to treat HPV+ HNSCC patients compared to HPV - HNSCC patients [72,73]. These results suggest that antitumor immune regulations might be extremely complex and cannot be explained as a dichotomic concept. Here, we summarize diverse aspects of immune components and patient outcomes, to better understand the current status, limitations, and future directions. 
As of now, the abundance of tumor infiltrating lymphocytes (TILs) is the most convincing prognostic immune marker in HNSCC, as well as several other cancers [74]. HPV+ HNSCC generally shows higher levels of $\mathrm{T}$ cell infiltration, particularly CD8+ T cells, and better clinical outcomes by standard therapy (Figure 2) [75-79]. Over 60\% of HPV+ oropharyngeal squamous cell carcinoma (OPSCC) patients show accumulation of stromal or intratumoral CD8+ TIL. Both stromal and intratumoral CD8+ TIL abundance is highly correlated to patient survival [76]. However, the correlation between CD8+ TIL and patient survival seems obscure in HPV - HNSCC [78]. This may be caused by the specific anatomical site that is highly prevalent for HPV+ HNSCC, the oropharynx, where immune cells are relatively abundant. The TME of HPV+ HNSCC also contains higher levels of CD4+ TILs than the HPV - HNSCC TME. While the prognostic value of the CD4+ TILs is still controversial, a subpopulation of CD4+CD161+ TILs specific to HPV16 positively correlates to patient overall survival [77]. In addition, a recent single cell RNA-seq study of the immune landscape in HPV+ and HPV - HNSCC has revealed that a CD4+ T follicular helper (TFH) cell-related gene expression signature is associated with longer progression-free survival in HNSCC patients [16]. However, it is unclear whether the favorable outcome is due to the antibody reaction mediated by $\mathrm{T}$ follicular helper cells, or a mere correlation is caused by the broad enhancement of immune responses [80-82].

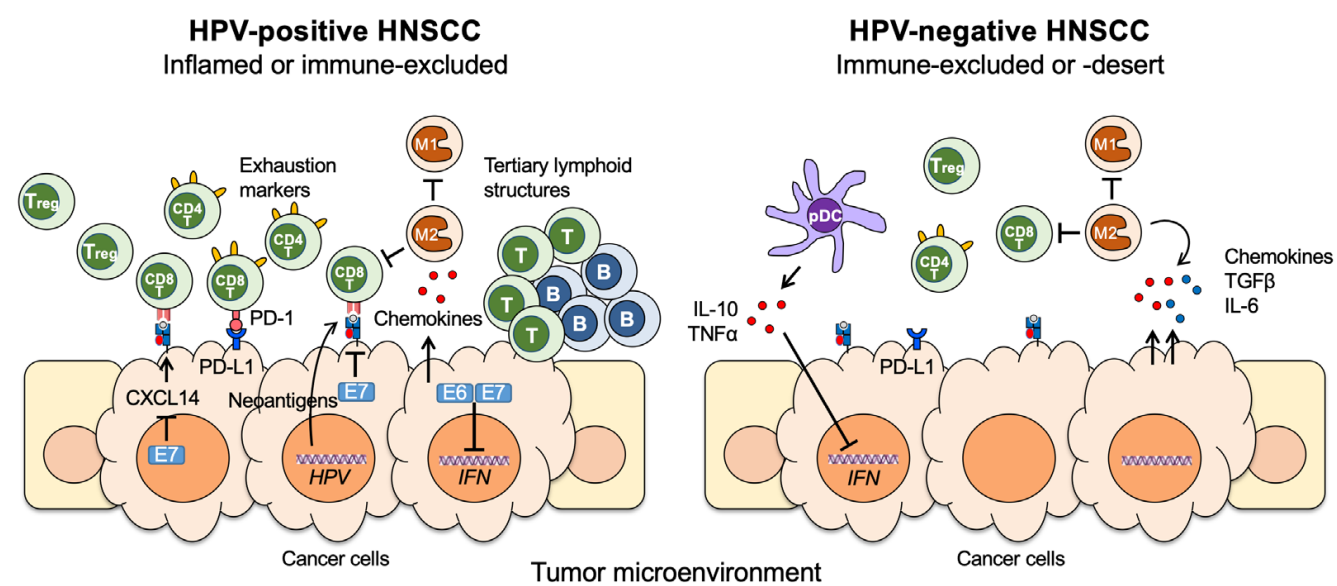

Figure 2. A summary of immune dysregulation and evasion in the tumor microenvironment (TME) of HPV+ (left) and HPV - (right) HNSCCs. The differential immunophenotypes in the TME between $\mathrm{HPV}+$ and HPV - HNSCC are depicted, based on three different spatial distribution of CD8 ${ }^{+} \mathrm{T}$ cells previously proposed $[83,84]$. The highly inflamed phenotype of HPV+ OPSCC may be caused by the anatomical distinction of oropharynx composed of the lymphoid tissue. CD4T, CD4 ${ }^{+} \mathrm{T}$ cell; CD8T, $\mathrm{CD}^{+}$T cell; Treg, regulatory T cell; B, B cell; T, T cell; M1, M1 macrophage; M2, M2 macrophage; pDC, plasmacytoid dendritic cell; HPV, HPV genome; IFN, interferon-related genes; TNF $\alpha$, tumor necrosis factor- $\alpha$; TGF $\beta$, transforming growth factor- $\beta$; PD-1, programmed death-1; PD-L1, programmed death ligand-1; IL-6, interleukin 6; IL-10, interleukin 10; CXCL14, C-X-C chemokine 14.

Interestingly, HPV+ HNSCC shows a significantly higher expression of the immune checkpoint protein PD-1 than HPV- HNSCC (Figure 2). Despite PD-1 playing a key role in inhibiting antitumor effector $\mathrm{T}$ cell functions, several studies have shown that the high levels of PD-1 expression in HNSCC is associated with better patient outcome. Indeed, Bhatt et al. have revealed that HPV16-specific $\mathrm{T}$ cells are abundant and reactive to almost all viral proteins, E1, E2, E4, E5, and L1, in addition to E6 and E7 [85,86]. These findings suggest that exhausted T cells specific to HPV may indicate previous antitumor immune activation against tumor cells expressing viral antigens, and still maintain certain antitumor potentials. In contrast, the correlation between PD-1 expression and patient outcome is still confusing in HPV - HNSCC [81,87]. Unlike PD-1, high PD-L1 expression on tumor cells correlates to favorable patient survival in HPV - HNSCC, but not in HPV+ HNSCC, while high PD-L1 expression on macrophages is associated with better prognosis $[88,89]$. 
Compared to HPV - HNSCC, HPV+ HNSCC also shows a higher expression of Th1 and exhaustion markers, such as CD39, LAG3, PD1, TIGIT, and TIM3 [90]. The expression levels of these $\mathrm{T}$ cell exhaustion markers correlate to overall survival of patients with HPV+ HNSCC, but not with HPV - HNSCC [90]. These results imply that reactivation of the exhausted T cells, a significant portion of which might recognize HPV-specific antigens, could be a useful strategy to treat HPV+ HNSCC patients. However, it is still possible that the T cells recognize other tumor-specific antigens generated in HPV+ HNSCC, as a previous study revealed that the majority of tumor-reactive $\mathrm{T}$ cells in cervical cancer recognize tumor neoantigens from somatic mutations, or a germline-specific antigen rather than viral antigens [91].

While tumor antigen presentation by major histocompatibility complex I (MHC-I) is critical for antitumor T cell functions, MHC-I expression is controversial. Similar to several viruses, it is well known that HPV has multiple mechanisms through the oncoproteins E5 and E7 to downregulate MHC-I expression on virus-infected host cells (reviewed in [43]). Our previous studies have also shown that expression of all MHC-I $\alpha$ subunits except HLA$\mathrm{F}$ are significantly downregulated in normal keratinocytes containing high-risk HPV in an E7-dependent manner [92,93]. While high-risk HPV E7 is sufficient for the downregulation of HLA-B/C and HLA-E expression, low-risk HPV E7 conversely increases HLA-B/C and HLA-E expression. Further, the downregulation of HLA-C and HLA-E expression were also observed in HPV+ HNSCC, in a comparison using the TCGA RNA-seq data [92]. Wuerdemann et al., also found a loss of MHC-I protein expression more frequently in HPV+ HNSCC than HPV - HNSCC patient samples [89]. In contrast, another study reported that a group of genes in MHC-I and the peptide loading complex are significantly upregulated in HPV+ HNSCC [94]. This discrepancy might be caused by the limitations in the standard criteria of tissue sample collections, spatial and temporal heterogeneity, and appropriate technologies to detect MHC-I expression on cancer cell surface from patient tissues. Thus, further studies using more sophisticated and robust experimental approaches are required for conclusive results.

In addition to T cells, $\mathrm{B}$ cell infiltration into the TME is frequently observed and associated with a favorable prognosis [95]. Recent studies have revealed that HPV+ HNSCC has tertiary lymphoid structures (TLS) with germinal center tumor infiltrating B cells (TIL-Bs) and non-organized aggregates containing CD20+ TIL-Bs and CD8+ T cells (Figure 2) [96,97]. Wood et al. also found a B cell-specific gene signature in HPV+ HNSCC, in which the expression is distinct and significantly higher than in HPV- HNSCC [98]. These findings suggest the importance of B cell infiltration into the TME. However, it is still unclear if the TIL-Bs play an important role in antitumor immunity, or just act as bystanders correlated with high levels of TIL.

Tumor-associated M2 macrophages have been suggested as an adverse prognostic factor in HPV - HNSCC, showing that high infiltration of $\mathrm{CD}_{163^{+}}$macrophages is linked to poor patient survival (Figure 2) [99]. However, HPV+ HNSCC does not show this correlation despite a significantly increased infiltration of both M1/M2 and M2 macrophages in the stroma compared to HPV - HNSCC [99]. Infiltration of CD163+ type 2 conventional dendritic cells ( $\mathrm{CDC} 2$ ) into the TME correlates to a Th1 response and better patient survival in HPV+ HNSCC [100]. In contrast, plasmacytoid dendritic cells (pDCs), known as a protumor DC, significantly suppress IFN $\alpha$ production in HPV - HNSCC via secretion of IL-10 and TNF $\alpha$ in HPV - HNSCC (Figure 2) [101]. Additionally, there is a correlation between pDCs with Tregs in the TME of HPV- HNSCC but not in HPV+ HNSCC [101]. These results suggest that even similar types of macrophages and DCs function differently between HPV+ and HPV - HNSCC patients.

Another interesting difference is the serum levels of the inflammation marker Creactive protein (CRP), which are significantly higher in HPV+ HNSCC patients compared to HPV - HNSCC. However, high circulating CRP levels are associated with poor overall survival and recurrence-free survival only in HPV - HNSCC patients [102]. HPV+ HN- 
SCC patients have higher serum levels of CRP but better overall survival than HPVHNSCC patients.

A number of studies have shown the fundamental differences in immune responses between HPV+ and HPV - HNSCC. Nevertheless, recent immunotherapy trials using immune checkpoint inhibitors showed no significant difference between HPV + and HPVHNSCC in the response rate $[72,103,104]$. This is particularly interesting as it is well established that HPV+ HNSCC shows significantly higher expression levels of PD-1 and PD-L1 expression compared to HPV - HNSCC. Thus, it is critical to better understand what other immune factors contribute to antitumor immune responses to clear $\mathrm{HPV}+$ and HPV - HNSCCs differentially.

\section{Differential Contributions of Oral Microbiome to HPV+ and HPV- HNSCCs}

The human microbiome is the ecological system of commensal, symbiotic, and pathogenic microorganisms inhabiting our bodies [105]. Recent studies have shown that changes in microorganism species in the microbiome, despite many of them being commensal, contribute to host immune dysregulation and carcinogenesis [106-109]. Identification and exploration of the interplay between microorganisms and the human host may provide new insights to a novel treatment axis.

Five bacterial phyla, Firmicutes, Proteobacteria, Bacteroidetes, Fusobacteria, and Actinobacteria, are known to be dominant in the oral microbiota in both healthy individuals and HNSCC patients (Table 1) [110,111]. Nevertheless, significant differences in beta diversity in the microbiome have been observed between healthy buccal mucosal specimens and oral cancer and oropharyngeal tumor tissues [110]. HPV status was also shown to correlate to bacterial abundance. These differences seen when comparing HPV+ and HPV - HNSCC may be due to interactions between the oral microbiota and behavioral/viral risk factors, such as smoking, alcohol, and HPV infection. Firmicutes were increased in OPSCC whereas Bacteroidetes and Proteobacteria were decreased [111]. When looking at genus-level profiles, Haemophillus was found to be dominant in HPV - HNSCC samples, while Veillonella, Megasphaera, and Anaerolineae showed a higher abundance in HPV+ HNSCC compared to HPV - HNSCC [111,112]. Interestingly, a longitudinal study showed that HPV+ HNSCC patients who later tested negative for HPV infection post-treatment recorded changes in Veillonella, Lactobacillus, and Streptococcus abundance [111], suggesting a role of HPV related to microbiome expression profiles.

Table 1. Microbiome studies in HNSCC patients.

\begin{tabular}{|c|c|c|c|}
\hline Type & Samples & Population & Major Findings \\
\hline \multirow{4}{*}{$\begin{array}{l}\text { Longitudinal Cohort } \\
\text { Study }\end{array}$} & 59 (from 42 patients) & $\begin{array}{l}17 \mathrm{HNSCC}(7 \mathrm{HPV}+\mathrm{OPSCC}, 4 \\
\text { HPV- OPSCC, } 6 \mathrm{HPV}-\mathrm{OSC}) \\
25 \text { control }\end{array}$ & $\begin{array}{c}\text { Shift in bacterial abundance in HPV + OPSCC following } \\
\text { treatment; microbial diversity may be used as a } \\
\text { diagnostic for HNSCC [111] }\end{array}$ \\
\hline & 100 (from 50 patients) & $\begin{array}{l}\text { Tumor and non-tumor sites from } \\
\text { OSCC patients }\end{array}$ & $\begin{array}{l}\text { Increased richness and diversity in OSCC tumor sites; } \\
\text { higher prevalence of Prevotellaceae, Fusobacteriaceae, } \\
\text { Flavobacteriaceae, Lachnospiraceae, Peptostreptococcaceae, } \\
\text { and Campylobacteraceae in OSCC [110] }\end{array}$ \\
\hline & 83 & $\begin{array}{l}\text { Tumor and anatomically matched } \\
\text { normal tissue from oral cancer } \\
\text { and pre-cancer }\end{array}$ & Reduction of Firmicutes and Actinobacteria in cancer [112] \\
\hline & 383 & $\begin{array}{l}129 \text { HNSCC and } 254 \text { matched } \\
\text { controls }\end{array}$ & $\begin{array}{c}\text { Corynebacterium and Kingella are associated with a lower } \\
\text { risk of HNSCC [113] }\end{array}$ \\
\hline \multirow[t]{2}{*}{ Prospective study } & 38 & $\begin{array}{l}18 \text { oral cavity squamous cell } \\
\text { cancer (OCSCC), } 8 \text { pre-malignant } \\
\text { lesions, } 12 \text { control }\end{array}$ & $\begin{array}{c}\text { Fusobacterium, Prevotella, Alloprevotella-enriched in } \\
\text { OCSCC [114] }\end{array}$ \\
\hline & 51 & $\begin{array}{l}27 \text { smokers with and } 24 \text { without } \\
\text { HNSCC }\end{array}$ & $\begin{array}{l}\text { Higher relative abundance of bacteria involved in } \\
\text { xenobiotic and amine degradation in HNSCC [115] }\end{array}$ \\
\hline \multirow[t]{2}{*}{ Retrospective analysis } & 151 & $\begin{array}{l}\text { Oral squamous cell carcinoma } \\
\text { (OSCC) patients }\end{array}$ & $\begin{array}{l}\text { F. nucleatum-associated OSCC is associated with } \\
\text { favorable prognosis [116] }\end{array}$ \\
\hline & 325 & $\begin{array}{l}\text { Esophageal Cancer (300 SCC, } \\
12 \text { adenocarcinomas, } 13 \text { others) }\end{array}$ & $\begin{array}{l}\text { F. nucleatum is a potential biomarker for esophageal } \\
\text { cancer is associated with poor prognosis [117] }\end{array}$ \\
\hline
\end{tabular}


The impact of chronic alcohol consumption in the oral microbiome negatively correlates to the abundance of Lactobacillus, one of the most common probiotic microbes [118,119]. The decrease in Lactobacillus potentially enhances the alkaline-tolerant bacteria and promotes the growth of ethanol-related pathogens in the oral microbiome, such as Neisseria and Corynebacterium [120]. Corynebacterium, an aerobic, gram-positive genus in the Actinobacteria phylum, is associated with the breakdown of toxins found in cigarette smoke and oxidation of ethanol to acetaldehyde (Table 1) [113,121]. The catabolism of tobacco-related toxins slows down carcinogenesis, and accordingly, a higher abundance of Corynebacterium is correlated with a lower risk of HNSCC [113].

It is also important to consider that a majority of individuals in the high-risk category due to smoking, alcohol, and/or HPV infection do not develop cancer. One emerging factor to explain this variance is the diverse oral microbiota that differentially affects host immune responses to carcinogenesis. A comparison of the oral microbiome between smokers with and without HNSCC have shown that the smoker HNSCC patients have diminished populations of common commensal bacteria involved in carbohydrate metabolism, such as Selenomonas, Veillonella, and Kingella (Table 1) [114]. Alternatively, a pathway analysis showed a significant increase in bacterial taxa involved in xenobiotic degradation, such as Stenotrophomonas, otherwise absent in healthy individuals [115]. Despite both groups experiencing exposure to the harmful toxins of tobacco, the different oral microbiota is associated with significant different incidence of HNSCC, suggesting that the microbiome plays a role in HNSCC carcinogenesis.

Indeed, the Fusobacterium phylum has been discovered to play an important role in promoting HNSCC development independent of tobacco, alcohol, or HPV infection [110]. The bacterial species included in Fusobacterium are significantly enriched in HNSCC tissues, causing increased expression of virulence factors in the oral microbiome [110]. Metaanalysis of patient samples also showed a higher abundance of Fusobacterium in HNSCC tumor samples compared to both adjacent normal tissues and tissues from healthy individuals (Table 1) [110,116,122,123]. Ironically, however, patients with F. nucleatum-positive HNSCC showed a favorable prognosis compared to F. nucleatum-negative HNSCC patients [124], while F. nucleatum in esophageal cancer is associated with aggressive disease and poor survival [117]. This may be attributed to F. nucleatum-mediated modulation of local immunity via downregulation of TNFSF4 and PDGFR $\beta$ in fibroblasts, both of which are associated with poor prognosis of HNSCC patients [116]. Additionally, F. nucleatum was correlated to low tobacco and alcohol use, suggesting a role in the TME independent of the major risk factors of HNSCC.

Taken together, the oral microbiome plays an important role in HNSCC carcinogenesis. Interactions of the oral microbiota with the major risk factors of tobacco and alcohol can exacerbate their carcinogenic effects. While studies have shown differential microbiota expression associated with HPV infection, additional work is needed to uncover the effect of the altered oral microbiome on HNSCC carcinogenesis. Considering both anatomical location and HPV status, developing novel and combination therapies by targeting the microbiota has great potential to improve patient treatment and outcome.

\section{Race, Sex, and Disparity in HPV+ and HPV - HNSCCs}

There is a clear difference in incidence of HPV+ HNSCC in females compared to males. While the factors that contribute to sexual disparity are largely unknown, several interesting hypotheses have been suggested. As reviewed in Sabatini et al., [125], there may be varying levels of viral exposure to the oropharynx depending on the route of transmission (vaginalto-oral vs. penile-to-oral). Chatterjee et al. found intriguing differential gene expression profiles in rafts of tonsil, cervical, and foreskin keratinocytes, raising the question of tissue type specific cancer progression [126]. Another consideration is the protective effect of estrogen in cancer development [125]. Beyond differential hormone exposure, there is also the possibility of differential immune responses, such as a more robust antibodybased response occurring with cervical infection in females compared to males [125]. 
Interestingly, female patients with p16-positive OPSCC showed a higher incidence of HPV+ cervical cancer [127]. Even though the incidence of HPV+ OPSCC is lower in females, the immune response to HPV is important for cancer prevention, and those who are not able to mount an adequate immune response may be more susceptible to future HPV-associated cancers. The importance of the immune response to HPV in the oropharynx is supported by the significantly increased HPV-positive rate in the oropharynx of post renal transplant patients [128].

There is limited prospective clinical trial data regarding sex and racial differences in outcomes for OPSCC. A retrospective study showed a significantly lower survival rate for black patients with HPV - OPSCC, compared to white patients with HPV- OPSCC [129]. This racial disparity has also been observed in HPV+ OPSCC $[130,131]$. In contrast, a metanalysis by Stein et al. found no evidence of survival disparity in HPV-positive patients by race, while black patients with HPV - OPSCC still show lower survival rates compared to white patients [132]. A multicenter retrospective review by Fakhry et al. found improved survival in females with HPV+ HNSCC in the oropharynx only [133]. These conflicting results among the limited studies may be caused by inconsistent HPV test methods in different studies that detect p16, HPV16 DNA, and/or HPV16 RNA. Indeed, significant variability in HPV testing has been observed in National Cancer Data Base of OPSCC cases, particularly prior to 2015 [134].

To obtain reliable data to determine the degree of sex and race disparities in HNSCC, improved proportionate enrollment of all race and sex groups in prospective clinical trials and/or larger multi-institutional databases with rigorous HPV testing will be required. It will also be important to differentiate clinical outcomes regarding disease mechanisms (immune response, genetic variations, HPV variants, etc.) when comparing factors related to socioeconomic status and demographics.

\section{Clinical Management of HNSCC: The Role of HPV}

\subsection{Diagnosis, Staging, and Treatment}

Despite the complex molecular and immunologic differences between HPV+ and HPV - HNSCC, until recently, treatment approaches for both diseases were uniform. The standard approach for the treatment of HNSCC is multidisciplinary in nature. Diagnosis and staging are commonly initiated by an otolaryngologist with training and experience in HNSCC surgery. Appropriate staging through imaging and endoscopy guides the primary treatment approach. Effective treatment may include single modality or a combination of surgery, radiation, and chemotherapy, depending on the stage of the disease at diagnosis. Tumor size/invasion, location, and the extent of nodal involvement all play a large role in treatment decisions. Staging is a tool to help stratify these treatment decisions, however, is most used as a prognostic tool. Up until recently, HPV status did not play a major role in these guidelines. Recently, the American Joint Committee on Cancer (AJCC) released the eighth edition of the staging guidelines for HNSCC [135]. This guideline has gone through major changes to account for the prognostic significance of HPV status in primary OPSCC. In short, for HPV- OPSCC, no major changes were made, and the staging is comparable to other HPV - HNSCC. However, for HPV+ OPSCC, significant changes were incorporated, allowing for more advanced tumor $(\mathrm{T})$ and nodal $(\mathrm{N})$ stages to be included in overall lower stage groups. These changes are too detailed to encompass in this review, but in short, patients with HPV+ disease can be included in stage I and II categories, even with advanced nodal disease and larger primary tumors. Clinical stage III disease is now limited to those with large, invasive tumors (T4), or bulky $(\geq 6 \mathrm{~cm})$ positive lymph nodes. Pathologic stage III disease includes those with T3/4 primary tumors and N2 ( $\geq 5$ lymph nodes positive) disease. In a major deviation from other tumor sites, stage IV disease is reserved only for those with metastatic disease. It is important to consider the changes in staging when reviewing older literature, as a direct comparison of stage and outcome for HPV-positive and HPV-negative is not always intuitive. 
Incorporating these staging guidelines, treatment for early stage HNSCC often starts with surgical resection followed by observation in some situations. Radiation alone is also an acceptable option for early stage oropharyngeal, hypopharyngeal, and laryngeal tumors [136]. However, these cancers represent the minority of patients, as the most present with advanced disease (positive lymph nodes which do not always correlate to advanced stage with the AJCC eighth edition staging). Multimodality therapy is therefore required for the majority of these patients. For those with advanced stage disease, appropriate radiologic and medical evaluation is needed to determine surgical candidacy. The potential damage to regional tissues, vessels, and organs (i.e., epiglottis, larynx, carotid artery), as well as predicted functional outcome (swallowing/speaking/breathing) must be considered in this decision making. In those with resectable disease, without high risk of organ injury, surgery is often the preferred first approach [136]. In general, adjuvant therapy with radiation therapy is indicated for those with larger primary tumors or those with positive lymph nodes. In patients who undergo surgical resection, but have high risk features, as defined as lymph node extracapsular extension (ECE) or positive margins, adjuvant chemoradiotherapy is recommended based on findings from the MACH-NC meta-analysis [137]. For those who present with surgically unresectable tumors or are at risk of irreversible organ damage with associated poor post-surgical functional outcomes, definitive CRT remains the standard-of-care. CRT is the common approach for organ preservation strategies, particularly in hypopharyngeal and laryngeal tumors, where total laryngectomy is the surgical option. There is some suggestion that regardless of tumor volume, the combination of cisplatin and radiation may be a superior modality for HPVpositive OPSCC; however, this question has not been resolved due to lack of definitive randomized head-to-head trials to evaluate surgery with adjuvant therapy versus CRT. Finally, while the minority of patients present with distant metastatic disease, curative therapies do not exist and palliative treatment with immunotherapy (e.g., PD-1 inhibitors), chemotherapy, and directed radiotherapy are the primary treatment options [136].

\subsection{Surgery}

In comparison to the number of well controlled randomized prospective trials for OPSCC treated with CRT, there is a paucity of data for primary surgery as a treatment modality. The stratification based on HPV tests has only been a recent phenomenon in the CRT, as well as surgery clinical trials. Similar to other trials noting improved survival for the HPV+ HNSCC cohort, Heiduschka et al. showed improved survival for the patients both p16-positive and HPV DNA ISH-positive after surgery and adjuvant radiation [138]. Since the p16-negative (mostly HPV-) group has worse survival with CRT, there has been consideration of escalated surgery as an initial modality in HPV-OPSCC. An intriguing study from Spain looking at a mostly HPV - population found a similar survival in HPV+ and HPV - HNSCC cohorts after surgery followed by adjuvant radiation or adjuvant CRT in most of the patients [139]. Sload et al. reviewed the evidence for surgery with adjuvant treatment for HPV-OPSCC [140]. Three studies with limited case numbers showed no difference in survival or locoregional control between HPV + and HPV - OPSCC treated with surgery followed by adjuvant treatment (reviewed in [140]). Large, randomized trials are needed to further evaluate these findings.

Regarding treatment trends, with the improved survival noted in the HPV+ OPSCC patients with nonsurgical treatment, it is interesting to note a decrease in the number of HPV+ OPSCC treated with surgery from 2010 to 2014 [141]. This may reflect patient preference to avoid surgery when non-surgical options are available, or even could reflect the rapid expansion of de-escalation clinical trials for HPV+ OPSCC over the last decade. Surgery still plays a valuable role in the understanding of OPSCC. Surgery allows for analysis of patient tissue and HPV status beyond what is feasible with nonsurgical treatment. Rubek et al. found that nodal metastasis has 30\% lower HPV DNA compared to the primary tumor in a prospective transoral robotic surgery (TORS) cohort [142]. It is possible 
that HPV DNA loss occurs during migration from the primary tumor site to lymph nodes. However, this finding needs to be confirmed.

One of the arguments for surgery in HPV - OPSCC (especially, TORS) is the potentially improved quality of life in patients with early-stage cancer, by avoiding full dose CRT. However, Michaelsen et al. analyzed the previous studies of quality of life outcomes in OPSCC and found no significant difference between patients with surgical and nonsurgical treatment [143]. The caveat of these studies is the inconsistency of rigorous HPV testing. Unfortunately, an inherent limitation of many studies evaluating surgery for treatment of OPSCC is selection bias of resectable tumors in patients that are healthy enough to tolerate surgery. Despite this limitation, it is clear that outcomes are excellent for carefully selected early-stage HPV+ OPSCC patients treated with surgery [144]. In this single institution series where a significant number of patients refused adjuvant CRT after surgery, locoregional control was $98 \%$ and disease specific 5-year survival was 100\% [144]. Conclusions regarding superiority or equivalence of treatment will hinge on large clinical trials (ideally randomized), comparing surgery with adjuvant treatment to primary nonsurgical treatment of HPV+ OPSCC.

\subsection{Multimodality Treatment}

As HPV status was recognized as a distinct prognostic group, additional analyses revealed prognosis in HPV+ HNSCC compared to HPV - HNSCC was better, regardless of stage, tobacco use, alcohol use, or treatment strategy [145]. One of the first studies to focus on HPV as a prognostic group was a retrospective analysis of surgically-treated HNSCC by the National Cancer Institute in Milan, Italy (Table 2) [146]. In this cohort of 90 participants, 19\% were HPV+ (HPV 16/18 DNA by PCR) and had significantly improved overall and relapse-free survival. Additionally, none developed second primary tumors up to 5 years out of treatment. This led to additional prospective efforts to use HPV status as a correlative biomarker. Eastern Cooperative Oncology Group (ECOG) 2399 was a prospective organ preservation chemoradiation study for resectable stage III or IV oropharyngeal or laryngeal HNSCC, that included a correlative analysis based on HPV status [147]. The study utilized an induction chemotherapy regimen with carboplatin and paclitaxel followed by CRT. In this study, patients with HPV+ HNSCC had an improved response to induction chemotherapy. In addition to an improved response, those with $\mathrm{HPV}+$ disease had improved 2-year overall and progression-free survival [148]. These findings spawned further retrospective and prospective analyses of definitive treatment trials, which uniformly showed improved outcomes in HPV+ disease, as outlined in Table 2.

These outcomes, as well as a large analysis of $1907 \mathrm{HPV}+$ OPSCC [151], informed the changes made in the AJCC eighth edition staging manual, which separated OPSCC into HPV+ and HPV - diseases [135,152]. Definitive treatment guidelines now dichotomize the treatment approaches for these distinct disease subtypes [136]. 
Table 2. Key multimodality treatment trials demonstrating improved outcome in HPV+ HNSCC.

\begin{tabular}{|c|c|c|c|c|c|c|c|c|c|}
\hline Source & $\begin{array}{l}\text { Parent } \\
\text { Study }\end{array}$ & Years & Treatment & Design & $\begin{array}{l}\text { Number of } \\
\text { Patients in } \\
\text { Analysis }\end{array}$ & $\begin{array}{l}\text { Disease } \\
\text { Sites }\end{array}$ & $\begin{array}{l}\text { HPV As- } \\
\text { sessment }\end{array}$ & $\begin{array}{c}\% \\
\mathrm{HPV}+/ \mathrm{HPV}-\end{array}$ & Outcome (HPV+ vs. HPV-) \\
\hline $\begin{array}{l}\text { Licitra, } \\
\text { et al., 2006 } \\
\text { [146] }\end{array}$ & NA & 1990-1999 & $\begin{array}{c}\text { Surgery } \\
\text { followed by } \\
\text { RT }\end{array}$ & $\begin{array}{l}\text { Single- } \\
\text { arm, } \\
\text { retrospec- } \\
\text { tive }\end{array}$ & 90 & OP & $\begin{array}{l}\text { HPV } 16 / 18 \\
\text { DNA PCR }\end{array}$ & $19 / 81$ & $\begin{array}{l}\text { 5-year OS (79\% vs. } 46 \%) \\
5 \text {-year incidence tumor } \\
\text { relapse ( } 21 \% \text { vs. } 53 \%), 5 \text {-year } \\
\text { incidence second primary } \\
(0 \text { vs. } 12 \%)\end{array}$ \\
\hline $\begin{array}{l}\text { Fakhry, } \\
\text { et al., 2008 } \\
{[148]}\end{array}$ & E2399 & 2001-2004 & $\begin{array}{l}\text { IC followed } \\
\text { by CRT }\end{array}$ & $\begin{array}{l}\text { Single- } \\
\text { arm Phase } \\
\text { II }\end{array}$ & 96 & $\begin{array}{l}\text { OP, } \\
\text { Larynx }\end{array}$ & $\begin{array}{l}\text { HPV types } \\
16,33,35 \\
\text { DNA ISH }\end{array}$ & $39.6 / 60.4$ & $\begin{array}{c}\text { ORR to IC }(82 \% \text { vs. } 55 \% \\
p=0.01) \text { and CRT }(84 \% \text { vs. } \\
57 \% p=0.007,2-\text { year OS } \\
(95 \% \text { vs } 62 \%, p=0.005)\end{array}$ \\
\hline $\begin{array}{l}\text { Ang, et al., } \\
2010 \\
{[14]}\end{array}$ & $\begin{array}{l}\text { RTOG } \\
0129\end{array}$ & 2002-2005 & $\begin{array}{c}\text { CRT } \\
\text { (accelerated } \\
\text { fx vs. } \\
\text { standard RT) }\end{array}$ & $\begin{array}{l}\text { Randomized } \\
\text { phase III }\end{array}$ & 323 & $\mathrm{OP}$ & $\begin{array}{l}\text { HPV } 16,18, \\
31,33,35, \\
39,45,51, \\
52,56,58, \\
59, \text { and } 68 \\
\text { DNA ISH }\end{array}$ & $63.8 / 36.2$ & $\begin{array}{c}3 \text {-year OS }(82.4 \% \text {, vs. } 57.1 \% \\
p<0.001), 3 \text {-year PFS }(73.7 \% \\
\text { vs. } 43.4 \%, p<0.001)\end{array}$ \\
\hline $\begin{array}{l}\text { Rischin, } \\
\text { et al., 2010 } \\
\text { [149] }\end{array}$ & $\begin{array}{l}\text { TROG } \\
02.02\end{array}$ & 2002-2005 & CRT & $\begin{array}{l}\text { Randomized } \\
\text { phase III }\end{array}$ & 182 & OP & P16 IHC & $57.3 / 42.7$ & $\begin{array}{c}2 \text {-year OS (91\% vs. } 74 \% \\
p=0.004), 2 \text {-year FFS }(87 \% \\
\text { vs. } 72 \%, p=0.003)\end{array}$ \\
\hline $\begin{array}{l}\text { Posner, } \\
\text { et al., 2011 } \\
{[150]}\end{array}$ & TAX 324 & 1999-2003 & $\begin{array}{l}\text { IC followed } \\
\text { by CRT }\end{array}$ & $\begin{array}{l}\text { Randomized } \\
\text { Phase III }\end{array}$ & 111 & $\mathrm{OP}$ & $\begin{array}{l}\text { HPV E6/E7 } \\
\text { PCR }\end{array}$ & $50 / 50$ & $\begin{array}{l}\text { * OS }(79 \% \text { vs. } 31 \%, p<0.0001, \\
\text { PFS ( }(73 \% \text { vs. } 29 \%, p<0.0001) \\
\text { LRF ( } 13 \% \text { vs. } 42 \%, p=0.0006)\end{array}$ \\
\hline
\end{tabular}

* analysis was at 83 months for HPV+ and 82 months for HPV-.

\subsection{Low and Intermediate-Risk HPV+ HNSCC}

Further prognostic characterization of HPV+ disease has focused on the definition of low-risk and intermediate-risk disease. Based on clear prognostic differences identified from the Radiation Therapy Oncology Group (RTOG) 0129 study [14], the impact of nodal stage and tobacco use highlighted a distinct survival difference within HPV+ cases. Using a cutoff of greater than 10 pack/year history (PYH) smoking and AJCC seventh edition N2bN3 (bilateral or $>6 \mathrm{~cm}$ nodal involvement) for HPV+ HNSCC patients, survival mirrored HPV - HNSCC with less than 10 pack/year smoking history. The 3-year overall survival rate was $70.8 \%$ in this intermediate-risk group, contrary to $93.0 \%$ in the HPV+ patients with low-risk disease (<10 pack/year history, N0-N2a disease). This intermediate-risk group has been further defined to include those with T4 primary tumors. In a large analysis, by including those with T4 primary tumors and those who have advanced nodal status (N2bN3) or smoking history of $\geq 10$ pack/year, the HPV+ intermediate-risk group had a higher risk of mortality with an estimated 4-year OS of 68\% [153]. Of this group, those with T3N3 or T4N2-N3 disease have 4-year survival rates of $51 \%$, which is equivalent to advanced HPV - disease. Therefore, HPV status alone is not the only factor that contributes to patient outcome. While these tumor and nodal stages have been included in the new AJCC eighth edition staging manual, tobacco use has not. Currently, the proposed intermediate-risk $\mathrm{HPV}+$ disease category is based on AJCC seventh edition stage T1-2N2-N3 or T3-4N0-3 with $\geq 10$ pack/year smoking history OR $<10$ pack/year, stage T4N0-N3 or T1-3N23. Recent clinical trial efforts focus on treatment strategies for these distinct prognostic disease groups.

\subsection{Metastatic Disease: Do HPV+ HNSCC Patients Fare Better?}

While prognosis of HPV+ HNSCC is generally better than HPV - HNSCC, approximately $10 \%$ of patients still develop R/M disease $[14,148,149,154]$. Those with HPV+ HNSCC also have unique metastatic patterns, often with multiple organs involved and atypical sites, such as the bone and liver [155]. Additionally, the median time to development of distant metastases following curative treatment is longer than HPV- HNSCC, with one study demonstrating 16.4 vs. 7.2 months $(p=0.008)$ [156]. Furthermore, metastatic disease development after 5 years in HPV+ HNSCC patients has been described $[154,157]$. Despite these findings, those with HPV+ HNSCC and relapse following definitive therapy still have improved prognosis in terms of survival over their HPV - HNSCC. In one analysis, 2-year overall survival after relapse was 54.6\% in HPV+ HNSCC vs. 27.6\% in HPV - HNSCC [158]. This improved survival in part has been suspected to be related to more responsive disease. However, in a retrospective analysis of the landmark EXTREME 
trial evaluating platinum, fluorouracil, and the addition of cetuximab in R/M HNSCC, survival outcomes were better in both groups by adding cetuximab [159]. A sub-analysis demonstrated that HPV+ HNSCC did have improved survival in the R/M setting over their HPV - counterparts, however this was not statistically significant (12.6 vs. 9.7 months, $p=0.092$ ) [159]. The analysis is limited, however, as only $10 \%$ of evaluable participants had p16+ disease.

\subsection{Immunotherapy Trials: Impact of HPV Status}

As monoclonal antibody inhibitors of the PD-1 and PD-L1 interaction have emerged as the preferred treatment option for R/M HNSCC, sub-analyses of outcomes based on HPV status have been performed. In the phase IB KEYNOTE-012 study evaluating the pembrolizumab monotherapy in an R/M HNSCC cohort, 23\% of participants were HPV+ based on p16 status [103]. Response rates were higher in those with HPV+ HNSCC (ORR $24 \%$ vs. 16\%) [160]. However, in the larger, phase II KEYNOTE-055 study evaluating pembrolizumab monotherapy in R/M HNSCC after progression on platinum therapy, ORRs were similar in those with HPV+ $(16 \%, 95 \%$ CI 6-32) and HPV- disease (15\%, 95\% CI 10-23) [104]. The landmark phase III CHECKMATE-141 study compared the PD-1 inhibitor, nivolumab, to second-line chemotherapies in R/M HNSCC. Of those tested and successfully treated with nivolumab, $26.4 \%$ of participants had HPV+ HNSCC based on p16 status and $20.8 \%$ HPV - HNSCC. While the aggregate study population had an improved OS with nivolumab treatment in this study, a post hoc analysis revealed that this survival benefit was more profound in HPV+ HNSCC patients (Supplementary Figure $\mathrm{S} 4$ in [72]). Interestingly, expression of PD-L1 ( $\geq 1 \%$ expression by IHC) was a stronger biomarker for this survival benefit, however even those with HPV+ PD-L1 negative disease had improved OS with nivolumab compared to chemotherapy (OS 10 vs. 6.4 months, HR 0.55 95\% CI 0.22-1.39). This difference was not seen in HPV- PD-L1 expressing HNSCC (OS 7.1 vs. 7.4 months HR 0.82 95\% CI 0.82 (0.31-2.19)) [161]. A subsequent study with a neoadjuvant PD-1 inhibitor arm, CHECKMATE 358, evaluated neoadjuvant nivolumab for previously untreated, locally advanced HNSCC. In this study, the pathologic response to therapy was higher in the HPV+ HNSCC group $(n=4 / 17 ; 23.5 \%)$ than the HPV - group $(n=1 / 17 ; 5.9 \%)$ [162]. Taking these findings together, HPV+ HNSCC patients have shown marginal signal for increased clinical benefit from PD-1 blockade treatment over those with $\mathrm{HPV}$ - disease.

Based on these findings, evaluation of PD-L1 expression based on HPV status has been an area of interest. Early work by Lyford-Pike et al. demonstrated localized PD-L1 expression in the tonsillar reticulated epithelium of the deep crypts, which represent the site of HPV-associated carcinogenesis [163]. Additionally, the authors demonstrated higher PD-L1 staining by immunohistochemistry ( $\geq 5 \%$ cells positive) in HPV+ HNSCC (14/20; $70 \%$ positive) compared to HPV - HNSCC (2/7; 29\% positive) [163]. Larger studies have shown a higher expression in HPV+ HNSCC than HPV - HNSCC [164-166], while no other marker shows a significant difference in expression by HPV status $[167,168]$. These findings have been criticized, however, as there has been significant heterogeneity in scoring systems and assays utilized [169]. Regardless, it is apparent that a benefit from PD-1 blockade is seen in both HPV+ and HPV - HNSCCs. While PD-L1 expression shows some benefits in predicting the treatment response, it is not definitive. PD-L1 inhibitors emerged as the preferred standard-of-care for many patients with R/M HNSCC, and are moving into earlier stage disease. Thus, novel biomarkers are being investigated to enrich treatment strategies.

\section{Current Treatment Approaches for HPV+ and HPV- HNSCC}

\subsection{De-Intensification or Intensification: Risk Adapted Therapy}

While multimodality therapy is often utilized across the anatomic sites of HNSCC, the management of OPSCC has become increasingly complex as our understanding of HPV status has grown. Patients with HPV+ OPSCC often present with advanced nodal disease 
at diagnosis and are not candidates for surgical resection, either due to having unresectable disease or a high risk of morbidity. Surgical innovations including TORS have emerged as a strategy to minimize the morbidity through use of natural orifice access approaches to the surgical site. TORS has been shown to optimize post-operative functional outcomes for carefully selected patients compared to traditional open approaches. However, large volume tumors or loss of important anatomic structures would still result in poor functional outcomes, regardless of the approach to the cancer. In addition, many TORS patients require adjuvant radiation or CRT as part of their treatment. Furthermore, as our understanding of the prognostic significance of HPV has grown, CRT approaches are evolving. Currently, the concept of de-intensification and intensification have emerged for HNSCC.

As previously discussed, in the clinical trial setting, patients presenting with locally advanced HPV+ HNSCC are being dichotomized into low-risk and intermediate-risk groups. In addition to staging, smoking status has a large impact on these risk groups. For those with low-risk disease, extensive efforts are being made to pursue de-intensification therapy. As the long-term cure rates exceed $90 \%$ in this risk group with standard treatment, there is strong support to consider reducing the intensity of treatment for this group to spare them from long-term toxicity. While this is not yet the standard-of-care, numerous clinical trials have been completed and are underway to determine the best strategy. Pivotal, randomized clinical trials that have been completed and that are actively accruing are outlined in Table 3. In summary, different approaches in surgical, post-operative radiation therapy (PORT), induction chemotherapy, addition of immunotherapy, and novel types of chemoradiotherapy are being evaluated. Thus far, completed phase III trials have not identified a clear strategy for de-escalation. Ongoing efforts seek to decrease radiation dose both with PORT and definitive therapy, as well as incorporate PD-1 blockades and novel chemotherapy regimens into treatment. Many centers are adopting these as part of their treatment approach through these clinical trials.

For those who present with intermediate-risk HPV+ HNSCC, treatment approaches are often the same as for those with HPV- HNSCC. For resectable patients, adjuvant RT at standard dose (typically $60 \mathrm{~Gy} / 2$ fractions per day over 6 weeks) is generally pursued unless there is very early-stage disease [136]. For those with the high-risk features of extranodal extension (ENE) or positive margins, or multiple intermediate risk features (lymphovascular invasion or LVI, perineural invasion or PNI ( $>3$ positive lymph nodes), adjuvant cisplatin-based CRT is the standard [136]. Many of those with HPV+ intermediaterisk HNSCC present with advanced T-stage (T4) and N-stage (N2-3), and are not candidates for surgical resection. Consequently, cisplatin-based CRT (70 Gy/2 fractions per day over 7 weeks) is often the mainstay of treatment for this group as a definitive therapy. As the cure rates for this population remain stagnant and inferior to low-risk HPV+ HNSCC, treatment intensification clinical trials have emerged as the investigational approach. As those with $\mathrm{HPV}+$ intermediate-risk HNSCC have comparable prognosis to patients presenting with HPV - HNSCC, these groups are often included in these trials together. Table 4 outlines past and current treatment intensification approaches. 
Table 3. Key de-intensification trials in HPV+ HNSCC.

\begin{tabular}{|c|c|c|c|c|c|c|}
\hline Trial & $\begin{array}{l}\text { Design (No. of } \\
\text { Patients) }\end{array}$ & Patient Population & $\begin{array}{c}\text { De-Escalation Strategy and } \\
\text { Regimens (* De-Escalation Arm) }\end{array}$ & $\begin{array}{c}\text { Primary Outcome } \\
\text { Measure }\end{array}$ & Status & $\begin{array}{l}\text { Summary of Findings } \\
\text { (if Completed) }\end{array}$ \\
\hline RTOG 1016 [170] & $\begin{array}{c}\text { Randomized, } \\
\text { noninferiority phase } \\
3(n=987)\end{array}$ & $\begin{array}{l}\text { AJCC 7th ed. T1-T2, N2-3 or } \\
\text { T3-T4, N0-N3; any } \\
\text { smoking history }\end{array}$ & $\begin{array}{l}\text { Chemotherapy } \\
\text { - Cetuximab } 400 \mathrm{mg} / \mathrm{m}^{2} \text { then } \\
250 \mathrm{mg} / \mathrm{m}^{2} \mathrm{q} 1 \mathrm{w} \times 7+\mathrm{RT} \\
(70 \mathrm{~Gy} / 35 \mathrm{fx} \text { in } 6 \text { weeks }) \\
\text { - Cisplatin }\left(100 \mathrm{mg} / \mathrm{m}^{2}\right) 3 \mathrm{w} \times 2+ \\
\text { RT }(70 \mathrm{~Gy} / 35 \mathrm{fx} \text { in } 6 \text { weeks })\end{array}$ & OS & Completed & $\begin{array}{l}\text { Cetuximab was not } \\
\text { shown to be non-inferior } \\
\text { to cisplatin }\end{array}$ \\
\hline $\begin{array}{l}\text { De-ESCALaTe } \\
{[171]}\end{array}$ & $\begin{array}{l}\text { Randomized phase } 3 \\
\qquad(n=334)\end{array}$ & $\begin{array}{c}\text { AJCC 7th ed. T3-T4, N0 or T1-T4, } \\
\text { N1-N3; <10 PYH }\end{array}$ & $\begin{array}{l}\text { Chemotherapy } \\
\text { - } \quad \text { Cetuximab } 400 \mathrm{mg} / \mathrm{m}^{2} \\
\text { then } 250 \mathrm{mg} / \mathrm{m}^{2} \mathrm{q} 1 \mathrm{w} 7+\mathrm{RT} \\
(70 \mathrm{~Gy} / 35 \mathrm{fx} \text { in } 6 \text { weeks }) \\
\text { - Cisplatin }\left(100 \mathrm{mg} / \mathrm{m}^{2}\right) 3 \mathrm{w} \times 3+ \\
\mathrm{RT}(70 \mathrm{~Gy} / 35 \mathrm{fx} \text { in } 6 \text { weeks })\end{array}$ & OS and late toxicity & Completed & $\begin{array}{l}\text { Mean number of severe } \\
\text { events and all grade } \\
\text { toxicity the same in } \\
\text { both groups }\end{array}$ \\
\hline TROG 12.01 [172] & $\begin{array}{l}\text { Randomized phase } 3 \\
\qquad(n=189)\end{array}$ & $\begin{array}{l}\text { AJCC 7th ed. Stage III (excluding } \\
\text { T1-2N1) or stage IVA-B (excluding } \\
\text { T4 and/or N3 and/or N2b-c); } \\
\leq 10 \text { PYH of smoking }\end{array}$ & $\begin{array}{l}\text { Chemotherapy } \\
\text { - Cetuximab } 400 \mathrm{mg} / \mathrm{m}^{2} \text { then } \\
250 \mathrm{mg} / \mathrm{m}^{2} \mathrm{q} 1 \mathrm{w} \times 7+\mathrm{RT} \\
(70 \mathrm{~Gy} / 35 \mathrm{fx} \text { in } 6 \text { weeks }) \\
\text { - Cisplatin }\left(40 \mathrm{mg} / \mathrm{m}^{2}\right) 1 \mathrm{w} \times 7+ \\
\text { RT }(70 \mathrm{~Gy} / 35 \mathrm{fx} \text { in } 6 \text { weeks })\end{array}$ & $\begin{array}{l}\text { Difference in AUC of } \\
\text { MDADI from baseline } \\
\text { to } 13 \text { weeks } \\
\text { post-therapy }\end{array}$ & Completed & $\begin{array}{l}\text { No difference in AUC of } \\
\text { MDADI between groups; } \\
\text { Worse 3-year FFS in } \\
\text { cetuximab (80\% [95\% CI: } \\
70-87 \%] \text { vs. cisplatin } \\
(93 \% \text { [95\% CI: } 86-97 \%])\end{array}$ \\
\hline $\begin{array}{l}\text { ORATOR } \\
\text { [173] }\end{array}$ & $\begin{array}{l}\text { Randomized Phase II } \\
\qquad(n=68)\end{array}$ & $\begin{array}{c}\text { AJCC 7th ed. T1-T2, N0-2 } \\
(\leq 4 \mathrm{~cm}) ; \text { any smoking history }\end{array}$ & \begin{tabular}{l}
\multicolumn{1}{c}{ Surgery } \\
- $\quad$ TORS and neck dissection+/- \\
adjuvant RT or CRT (based on \\
pathology) \\
CRT (RT 70 Gy, various chemo \\
regimens)
\end{tabular} & $\begin{array}{l}\text { 1-year swallowing QoL } \\
\text { by MDADI }\end{array}$ & Completed & $\begin{array}{l}\text { 1-year MDADI score } \\
\text { higher in RT group }\end{array}$ \\
\hline ECOG 3311 [174] & $\begin{array}{l}\text { Randomized phase II } \\
\qquad(n=519 \text { overall, } \\
209 \text { Arms B and C) }\end{array}$ & $\begin{array}{l}\text { AJCC } 7 \text { th ed. stage III-IVA } \\
\text { resected, intermediate pathologic } \\
\text { risk (close margins }[<3 \mathrm{~mm}], 2-4+ \\
\text { nodes or } 1 \text { node }>3 \mathrm{~cm} \text { and } \leq 6 \mathrm{~cm}, \\
\text { ENE } \leq 1 \mathrm{~mm} \text {, or PNI/LVI); any } \\
\text { smoking history }\end{array}$ & $\begin{array}{c}\text { PORT } \\
\text { • } \quad \text { *50 Gy PORT Arm B } \\
\text { - } \quad 60 \text { Gy PORT Arm C }\end{array}$ & 2-year PFS & Completed & $\begin{array}{c}\text { 2-year PFS similar in } \\
\text { Arm B } 95.0 \% \\
(90 \% \text { CI }=91.4 \%, 98.6 \%) \\
\text { to ARM C } 95.9 \% \\
(90 \% \text { CI }=92.6 \%, 99.3 \%)\end{array}$ \\
\hline
\end{tabular}


Table 3. Cont.

\begin{tabular}{|c|c|c|c|c|c|c|}
\hline Trial & $\begin{array}{l}\text { Design (No. of } \\
\text { Patients) }\end{array}$ & Patient Population & $\begin{array}{c}\text { De-Escalation Strategy and } \\
\text { Regimens (* De-Escalation Arm) }\end{array}$ & $\begin{array}{c}\text { Primary Outcome } \\
\text { Measure }\end{array}$ & Status & $\begin{array}{l}\text { Summary of Findings } \\
\text { (if Completed) }\end{array}$ \\
\hline $\begin{array}{c}\text { NRG-HN002 } \\
\text { [175] }\end{array}$ & $\begin{array}{l}\text { randomized, phase II } \\
\quad \text { trial }(n=306)\end{array}$ & $\begin{array}{c}\text { AJCC 7th ed. T1-T2 N1-N2b M0, } \\
\text { or T3 N0-N2b M0; } \leq 10 \mathrm{PYH} \\
\text { of smoking }\end{array}$ & $\begin{array}{l}\text { No chemotherapy } \\
\text { - } \quad \text { *60 Gy IMRT over } 5 \text { weeks } \\
60 \text { Gy IMRT over } 6 \text { weeks + cis- } \\
\text { platin } 40 \mathrm{mg} / \mathrm{m}^{2} \mathrm{Q} 1 \mathrm{w} \times 6 \\
\text { PORT }\end{array}$ & $\begin{array}{l}\text { 2-year PFS and 1-year } \\
\text { swallowing QoL by } \\
\text { MDADI }\end{array}$ & Completed & $\begin{array}{l}\text { Similar 2-year PFS ( } 88 \% \\
\text { RT vs. 91\% CRT), but RT } \\
\text { alone did not meet } \\
\text { pre-specified 2-year } \\
\text { PFS goal }\end{array}$ \\
\hline $\begin{array}{c}\text { PATHOS } \\
\text { [NCT02215265] }\end{array}$ & $\begin{array}{l}\text { Randomized phase } \\
\text { II/II ( } n=\text { up to } 1100)\end{array}$ & $\begin{array}{l}\text { AJCC 7th ed. T1-T3, N0-N2b } \\
\text { 8th edition stage T1-T3, N0-N1; } \\
\text { Any smoking history (except } \\
\text { current smokers with } \\
\text { N2b disease) }\end{array}$ & $\begin{array}{l}\text { - Arm B1: PORT } 60 \text { Gy over } \\
6 \text { weeks } \\
\text { * Arm B2: PORT } 50 \text { Gy over } \\
5 \text { weeks } \\
\text { - Arm C1: POCRT } 60 \text { Gy over } \\
6 \text { weeks with Cisplatin (high risk } \\
\text { features) } \\
\text { * Arm C2: PORT } 60 \text { Gy over } \\
6 \text { weeks without chemotherapy } \\
\text { (high risk features) }\end{array}$ & $\begin{array}{l}\text { 1-year MDADI and } \\
\text { Overall survival }\end{array}$ & Ongoing & NA \\
\hline $\begin{array}{l}\text { NRG-HN005 } \\
\text { [NCT03952585] }\end{array}$ & $\begin{array}{l}\text { Randomized phase } \\
\text { II/III ( } n=\text { up to } 711)\end{array}$ & $\begin{array}{c}\text { AJCC 8th ed. 8th T1-2N1M0 or } \\
\text { T3N0-N1M0; } \leq 10 \mathrm{PYH} \\
\text { of smoking }\end{array}$ & $\begin{array}{l}\text { Radiation and chemotherapy } \\
\text { - } \quad \text { Arm 1: RT } 70 \text { Gy over } 6 \text { weeks + } \\
\text { Cisplatin } 100 \mathrm{mg} / \mathrm{m}^{2} \mathrm{Q} 3 \mathrm{w} \times 2 \\
\text { - } \quad \text { *Arm 2: RT } 60 \text { Gy radiation over } \\
3 \text { weeks + Cisplatin } 100 \mathrm{mg} / \mathrm{m}^{2} \\
\text { Q3w } \times 2 \\
\text { * Arm 3: RT } 60 \text { Gy over } 3 \text { weeks } \\
\quad+\text { Nivolumab } 240 \mathrm{mg} \text { Q2w } \times 6\end{array}$ & $\begin{array}{l}\text { Phase II, PFSPhase III, } \\
\text { PFSand QoL by the } \\
\text { MDADI global score }\end{array}$ & Ongoing & NA \\
\hline $\begin{array}{c}\text { DART-HPV } \\
\text { [NCT02908477] }\end{array}$ & $\begin{array}{l}\text { Randomized phase } \\
\quad \text { III }(n=227)\end{array}$ & $\begin{array}{l}\text { TORS resected primary disease } \\
\text { with either AJCC 8th ed. T3/4 or } \\
\text { N2b disease, and/or ENE, } \\
\text { LVI, PNI }\end{array}$ & $\begin{array}{l}\text { POCRT } \\
\text { - } \quad \text { RT } 30 \mathrm{~Gy} / 1.5 \mathrm{~Gy} \text { fractions BID } \\
\text { (intermediate risk) or 36 Gy } / 1.8 \\
\text { Gy BID fractions (high risk) + Do- } \\
\text { cetaxel } 15 \mathrm{mg} / \mathrm{m}^{2} \text { days } 1,8 \\
\text { RT } 60 \mathrm{~Gy} / 2 \mathrm{~Gy} \text { fractions daily } \\
\text { alone (intermediate risk) or with } \\
\text { cisplatin } 40 \mathrm{mg} / \mathrm{m}^{2} \mathrm{Q} 1 \mathrm{w} \times 6 \\
\text { (high risk) }\end{array}$ & $\begin{array}{l}\text { Adverse event rate } \\
\text { (late grade 3-5 } \\
\text { toxicities) }\end{array}$ & Ongoing & NA \\
\hline
\end{tabular}


Table 4. Selected treatment intensification trials.

\begin{tabular}{|c|c|c|c|c|c|c|}
\hline Trial & $\begin{array}{l}\text { Design (No. of } \\
\text { Patients) }\end{array}$ & Patient Population & $\begin{array}{l}\text { Intensification Strategy and Regimens } \\
\left({ }^{*} \text { Intensification Arm) }\right.\end{array}$ & $\begin{array}{c}\text { Primary Outcome } \\
\text { Measure }\end{array}$ & Status & $\begin{array}{l}\text { Summary of Findings } \\
\text { (if Completed) }\end{array}$ \\
\hline RTOG 0129 [176] & $\begin{array}{l}\text { Randomized Phase III } \\
\quad(n=721)\end{array}$ & $\begin{array}{l}\text { AJCC 6th ed. Stage III-IVB OC, OP, HP, } \\
\text { Larynx; any HPV risk group }\end{array}$ & $\begin{array}{l}\text { Accelerated fraction (AFX) RT } \\
\text { - } \quad \text { AFX: } 72 \mathrm{~Gy} \text { in } 42 \mathrm{fx} \text { over } 6 \text { weeks + } \\
\text { Cisplatin } 100 \mathrm{mg} / \mathrm{m}^{2} \mathrm{Q} 3 \mathrm{~W} \times 2 \\
\text { SFX RT } 70 \mathrm{~Gy} \text { in } 35 \mathrm{fx} \text { over } 7 \text { weeks + } \\
\text { Cisplatin } 100 \mathrm{mg} / \mathrm{m}^{2} \mathrm{Q} 3 \mathrm{~W} \times 3 \\
\text { Combination chemotherapy }\end{array}$ & OS & Completed & $\begin{array}{l}\text { No difference in OS (HR, } 0.96 \text {; } \\
95 \% \mathrm{CI}, 0.79 \text { to } 1.18 ; p=0.37) \text {. }\end{array}$ \\
\hline RTOG 0522 [177] & $\begin{array}{l}\text { Randomized Phase III } \\
\qquad(n=891)\end{array}$ & $\begin{array}{l}\text { AJCC 6th ed. stage III-IVB OC, OP, HP, } \\
\text { Larynx; any HPV risk group }\end{array}$ & $\begin{array}{l}\text { - } \\
\text { Q3W 1: AFX RT + Cisplatin } 100 \mathrm{mg} / \mathrm{m}^{2} \\
\text { - Arm 2: AFX RT + Cisplatin } 100 \\
\mathrm{mg} / \mathrm{m}^{2} \text { Q3W } \times 2+\text { Cetuximab } 400 \\
\mathrm{mg} / \mathrm{m}^{2} \text { then } 250 \mathrm{mg} / \mathrm{m}^{2} \mathrm{q} 1 \mathrm{w} \times 7\end{array}$ & PFS & Completed & $\begin{array}{l}\text { No difference in PFS, OS, LRF. } \\
\text { Higher acute toxicities with the } \\
\text { addition of cetuximab }\end{array}$ \\
\hline PARADIGM [178] & $\begin{array}{l}\text { Randomized Phase III } \\
\qquad(n=145)\end{array}$ & $\begin{array}{l}\text { AJCC 6th ed. Stage IVA-IVB (T3/T4 or } \\
\text { N2/N3, but not T1/N2) OC, OP, } \\
\text { Larynx; any HPV risk group }\end{array}$ & $\begin{array}{l}\text { Induction chemotherapy } \\
\text { - Arm 1: Docetaxel } 75 \mathrm{mg} / \mathrm{m}^{2}, \text { Cis- } \\
\text { platin } 80 \mathrm{mg} / \mathrm{m}^{2}, 5-\mathrm{FU} 800 \mathrm{mg} / \mathrm{m}^{2} / \mathrm{d} \\
\text { days } 1-4 \mathrm{Q} 3 \mathrm{w} \times 3 \text { followed by CRT } \\
\text { with carboplatin or docetaxel } \\
\text { Arm 2: AFX RT + cisplatin } 100 \mathrm{mg} / \mathrm{m}^{2} \\
\mathrm{Q} 4 \mathrm{~W} \times 2\end{array}$ & OS & Completed & $\begin{array}{l}\text { No difference in OS (HR, 1.09; } \\
95 \% \text { CI } 0.59-2.03) \text {. poor accrual } \\
\text { (145 of } 300 \text { planned) }\end{array}$ \\
\hline $\begin{array}{l}\text { KEYNOTE-412 } \\
\text { [NCT03040999] }\end{array}$ & $\begin{array}{l}\text { Randomized Phase III } \\
\quad(n=780 \text { planned })\end{array}$ & $\begin{array}{c}\text { AJCC 7th ed OP HPV+ (any T4 or N3), } \\
\text { OP HPV- (any T3-T4 or N2a-N3), or } \\
\text { larynx/HP/OC (any T3-T4 or } \\
\text { N2a-N3) }\end{array}$ & $\begin{array}{l}\text { * Pembrolizumab + CRT (AFX or SFX } \\
70 \text { Gy) + Cisplatin } 100 \mathrm{mg} / \mathrm{m}^{2} \mathrm{Q} 3 \mathrm{~W} \times \\
2-3 \\
\text { CRT (AFX or SFX } 70 \mathrm{~Gy})+ \text { Cisplatin } \\
100 \mathrm{mg} / \mathrm{m}^{2} \mathrm{Q} 3 \mathrm{~W} \times 2-3\end{array}$ & Event Free Survival (EFS) & Ongoing & NA \\
\hline
\end{tabular}


Table 4. Cont.

\begin{tabular}{|c|c|c|c|c|c|c|}
\hline Trial & $\begin{array}{l}\text { Design (No. of } \\
\text { Patients) }\end{array}$ & Patient Population & $\begin{array}{l}\text { Intensification Strategy and Regimens } \\
\left({ }^{*} \text { Intensification Arm) }\right.\end{array}$ & $\begin{array}{c}\text { Primary Outcome } \\
\text { Measure }\end{array}$ & Status & $\begin{array}{l}\text { Summary of Findings } \\
\text { (if Completed) }\end{array}$ \\
\hline $\begin{array}{l}\text { KEYNOTE-689 } \\
\text { [NCT03765918] }\end{array}$ & $\begin{array}{l}\text { Randomized Phase III } \\
\quad(n=704 \text { planned })\end{array}$ & $\begin{array}{l}\text { AJCC 8th ed. resectable, stage III/IVA } \\
\text { HPV - or T4N0-2 HPV+ }\end{array}$ & $\begin{array}{l}\quad \text { Neoadjuvant PD-1 blockade } \\
\text { * } \quad \text { Pembrolizumab Q3W } \times 2 \text { doses pre- } \\
\text { operatively followed by risk-adapted } \\
\text { PORT or POCRT (cisplatin) + pem- } \\
\text { brolizumab } \\
\text { - Surgery followed by adjuvant risk } \\
\text { adapted PORT or POCRT (cisplatin) }\end{array}$ & $\begin{array}{l}\text { Major Pathological } \\
\text { Response (mPR) and EFS }\end{array}$ & Ongoing & NA \\
\hline $\begin{array}{l}\text { RTOG } 1216 \\
\text { [NCT01810913] }\end{array}$ & $\begin{array}{l}\text { Randomized phase } \\
\text { II } / \text { III }(n=480 \\
\text { planned })\end{array}$ & $\begin{array}{l}\text { Resected AJCC 7th ed Stage III-IVB } \\
\text { HPV+ or HPV - disease with high-risk } \\
\text { features (ENE or positive margins) }\end{array}$ & $\begin{array}{l}\text { Adjuvant POCRT + PD-L1 blockade } \\
\text { POCRT } 60 \mathrm{~Gy}+\text { cisplatin } 40 \mathrm{mg} / \mathrm{m}^{2} \\
\text { Q1W } \times 6 \\
\text { POCRT } 60 \mathrm{~Gy}+\text { docetaxel } 15 \mathrm{mg} / \mathrm{m}^{2} \\
\text { Q1w } \times 6+\text { cetuximab + Cetuximab } \\
400 \mathrm{mg} / \mathrm{m}^{2} \text { then } 250 \mathrm{mg} / \mathrm{m}^{2} \mathrm{q} 1 \mathrm{w} \times 7 \\
\text { - } \quad \text { POCRT } 60 \mathrm{~Gy}+\text { cisplatin } 40 \mathrm{mg} / \mathrm{m}^{2} \\
\text { Q1W } \times 6+\text { Atezolizumab } 1200 \mathrm{mg} \\
\text { Q3W } \times 8\end{array}$ & Phase II-DFSPhase III-OS & Ongoing & NA \\
\hline
\end{tabular}


In summary, prior approaches have included accelerated fraction radiation, induction chemotherapy, and chemotherapy combinations with radiation. However, none of these have led to a deviation from the current standard of cisplatin-based CRT. With the activity of PD-1 inhibitors in R/M disease, there is excitement about their impact in the definitive setting. Initial studies demonstrated safety and early favorable efficacy signal [180]. However, one large, randomized trial of the PD-L1 inhibitor, avelumab, has already read out as negative, thus dampening the enthusiasm for these agents in this treatment setting [179]. While these unique treatment approaches are rapidly moving forward, the standard-of-care for curative intent therapy has remained the same for decades regardless of HPV status. While those with low-risk HPV+ disease enjoy high survival rates, some still will recur. For those with intermediate-risk HPV + disease and HPV - disease, relapse rates are generally higher. Those that recur or who present with metastatic disease at diagnosis have incurable disease. However, recent advances in therapies seek to improve outcome for these patients as well.

\subsection{Advances in the Treatment of Recurrent/Metastatic Disease: Implications of HPV Status}

Approximately 10-15\% of patients with HNSCC will develop R/M disease either at diagnosis or following treatment [181,182]. For these patients, systemic therapy remains the mainstay for disease control and optimization, quality of life, and survival. As mentioned above, PD-1 inhibitors have become the standard-of-care for most patients, either as monotherapy or in combination with chemotherapy. Despite there being no clear link between HPV status and response to these agents, significant efforts are being made to look at novel immunotherapy approaches to treat HPV+ HNSCC. Much of this has been led by the emergence of therapeutic vaccines. As HPV-infected cancer cells express viral oncoproteins, these represent antigenic targets for vaccine development. Several vaccines using different technologies have emerged. A number of viral vector- [183], DNA- [184], and peptide- [68] based therapeutic vaccines are in various stages of development. Due to the immunologic nature of response, combination with other immunotherapies is being pursued, including combinations with PD-1/PD-L1 inhibitors [185]. Taking this a step further, with the rapid growth of cell-based therapies in hematologic malignancies, HPV-specific cell-based therapies are gaining traction in HPV+ HNSCC. HPV16/18 E6/E7 adoptive T cell therapies are currently in early-phase clinical trials in HNSCC, and seek to bring cell-based therapies into the treatment of this disease (NCT03578406, NCT02379520) [186]. Other cell-based therapies, including one that targets melanoma-associated antigen 4 (MAGEA4), seek to expand cell-based therapy beyond HPV+ HNSCC (NCT04408898). Development of novel immunotherapies is rapidly moving forward, and in combination with these HPV-specific therapies is certain to be an area of future research.

Beyond immunotherapies, targeted therapies are another area of growing research in HNSCC. As discussed above, a number of different pathways are altered in HNSCC. Epidermal growth factor receptor (EGFR/ERBB1) and its family ERBB2 (HER2), ERBB3 (HER3), as well as FGFR kinase aberrations have been demonstrated in HNSCC (Figure 1). Cetuximab, a monoclonal antibody inhibitor of EGFR, has been an approved treatment both in combination with radiotherapy for definitive treatment and in the metastatic setting. Until recently, this agent was often utilized as a standard chemosensitizing agent with definitive chemoradiotherapy. However, recent findings from the De-ESCALaTE HPV, RTOG 1016, and TROG 12.01 trials (Table 3) in HPV+ HNSCC showed inferior results with cetuximab versus cisplatin as a CRT in the definitive setting. While this agent is still utilized in the R/M setting in HPV+ HNSCC, interest in the definitive setting has waned. Despite this, a pan-ERBB inhibitor, Aafatinib, achieved NCCN support for use for R/M HNSCC as second-line therapy following platinum failure, based on the LUX-HN study $[145,187]$. Beyond these receptor tyrosine kinases, potentially druggable alterations in other common downstream kinases including MAPK (HRAS, NRAS, KRAS, $B R A F, N F 1)$ and PI3K/AKT/mTOR pathway have been seen in HNSCC [188]. Of these, the PIK3CA mutation has been more commonly seen in HPV+ HNSCC [189], while HRAS 
mutations are more common in HPV- HNSCC [190]. Targeted therapies for each of these are being pursued, however development is not intentionally exclusive to HPV status [191,192]. Additional interest in the cell cycle pathway (CDK4/6, CCND1, CDKN2A) and DNA repair pathway (BRCA, ATM, PALB2) is growing, with trials underway in HNSCC as a whole [193-195]. As the molecular characteristics of HPV+ and HPV- HNSCCs are understood, it is surmised that disease-specific treatments will emerge.

\section{Conclusions}

As discussed above, there have been significant advances in our understanding of molecular mechanisms and improvement of clinical approaches in HNSCC. Nevertheless, there are more questions than answers from current research, as we currently do not have clear explanations on several important issues in HNSCC. First, it is still mysterious how HPV+ HNSCC patients show substantially better survival and clinical outcomes after standard-of-care treatment than HPV - HNSCC patients. Studies by ourselves and others have suggested potential factors, such as high cell proliferation and DNA damage rates of HPV+ cancer cells compared to HPV - cancer cells [5,196]. In contrast, several studies have suggested that HPV+ HNSCC in anatomical sites other than the oropharynx and tonsil does not show favorable outcomes [197-199]. However, as positive p16 immunohistochemistry for non-oropharyngeal head and neck cancers does not accurately represent HPV status [200,201], further molecular analyses and mechanistic studies would be necessary for any definitive answer. Second, the extreme bias of HNSCC prevalence in the male population is obvious but still unexplainable. Recent studies have discovered that females have more robust immune responses against various viruses, including HPV and SARS-CoV-2 [202,203]. The sex differences in immune responses and cancer development are suspected to be caused by sex hormones and differential behaviors between males and females [204,205]. Third, while expression levels of PD-1 and PD-L1 in HPV+ HNSCC are undoubtedly higher compared to HPV - HNSCC, there is no evident benefit from immunotherapy using PD-1/PD-L1 inhibitors. In addition, there is an urgent need to develop useful biomarkers available to identify the intermediate-risk group of HPV+ HNSCC and responders from non-responders to current therapies. A better understanding of microbiota linked to HNSCC would also be helpful, as the oral regions form an abundant and diverse microbial ecosystem that may contribute to immune dysregulation and carcinogenesis. Considering the extraordinary heterogeneity in HNSCC developed in the complex and dynamic anatomical sites, cancer cell evolution in interaction with proximal and distal organs could also be a new area to explore. Taken together, basic, translational, and clinical research in HNSCC during the next decade will bring about scientific breakthrough, as well as innovative treatment for cancer patients.

Author Contributions: Conceptualization, S.F.P., W.C.S. and D.P.; writing-original draft preparation, S.F.P., L.V., W.C.S. and D.P.; writing-review and editing, S.F.P., L.V., W.C.S. and D.P.; visualization, D.P.; supervision, S.F.P., W.C.S. and D.P.; funding acquisition, W.C.S. and D.P. All authors have read and agreed to the published version of the manuscript.

Funding: Our work was supported by the National Institutes of Health (R01 DE026125 and R01 DE029524 to D.P. and W.C.S.).

Conflicts of Interest: W.C.S. consulting for Bristol Myers Squibb, Regeneron, and Merck. S.F.P. received research grant support to the institution from Merck, Bristol Myers Squib, Pfizer, Vyriad, Incyte, Actuate, Genentech, and Seattle Genetics. Steven Powell received consulting support to the institution from Bristol Myers Squibb. The other authors declare no conflict of interest.

\section{Abbreviations}

RT radiation therapy

OP oropharynx

RFS relapse-free survival

OS overall survival 


\begin{tabular}{|c|c|}
\hline PFS & progression-free survival \\
\hline ORR & overall response rate \\
\hline LRF & locoregional failure \\
\hline IC & induction chemotherapy \\
\hline CRT & chemoradiotherapy \\
\hline ISH & in situ hybridization \\
\hline $\mathrm{IHC}$ & immunohistochemistry \\
\hline $\mathrm{Fx}$ & fractions \\
\hline Gy & Gray \\
\hline BID & twice a day \\
\hline AUC & area under the curve \\
\hline MDADI & MD Anderson Dysphagia Inventory \\
\hline PORT & post-operative radiation therapy \\
\hline POCRT & post-operative chemoradiotherapy \\
\hline IMRT & intensity modulated radiation therapy \\
\hline QoL & quality of life \\
\hline SFX & standard fraction \\
\hline
\end{tabular}

\section{References}

1. Siegel, R.L.; Miller, K.D.; Fuchs, H.E.; Jemal, A. Cancer Statistics, 2021. CA Cancer J. Clin. 2021, 71, 7-33. [CrossRef] [PubMed]

2. Gillison, M.L.; D'Souza, G.; Westra, W.; Sugar, E.; Xiao, W.; Begum, S.; Viscidi, R. Distinct risk factor profiles for human papillomavirus type 16-positive and human papillomavirus type 16-negative head and neck cancers. J. Natl. Cancer Inst. 2008, 100, 407-420. [CrossRef] [PubMed]

3. Goldenberg, D.; Lee, J.; Koch, W.M.; Kim, M.M.; Trink, B.; Sidransky, D.; Moon, C.S. Habitual risk factors for head and neck cancer. Otolaryngol. Head Neck Surg. 2004, 131, 986-993. [CrossRef] [PubMed]

4. Xu, M.; Yao, Y.; Chen, H.; Zhang, S.; Cao, S.M.; Zhang, Z.; Luo, B.; Liu, Z.; Li, Z.; Xiang, T.; et al. Genome sequencing analysis identifies Epstein-Barr virus subtypes associated with high risk of nasopharyngeal carcinoma. Nat. Genet. 2019, 51, 1131-1136. [CrossRef]

5. Pyeon, D.; Newton, M.A.; Lambert, P.F.; Boon, J.A.D.; Sengupta, S.; Marsit, C.; Woodworth, C.D.; Connor, J.P.; Haugen, T.; Smith, E.M.; et al. Fundamental differences in cell cycle deregulation in human papillomavirus-positive and human papillomavirusnegative head/neck and cervical cancers. Cancer Res. 2007, 67, 4605-4619. [CrossRef]

6. Gillison, M.L.; Akagi, K.; Xiao, W.; Jiang, B.; Pickard, R.K.L.; Li, J.; Swanson, B.J.; Agrawal, A.D.; Zucker, M.; Stache-Crain, B.; et al. Human papillomavirus and the landscape of secondary genetic alterations in oral cancers. Genome Res. 2019, 29, 1-17. [CrossRef]

7. Vokes, E.E.; Agrawal, N.; Seiwert, T.Y. HPV-Associated Head and Neck Cancer. J. Natl. Cancer Inst. 2015, 107, djv344. [CrossRef]

8. Stransky, N.; Egloff, A.M.; Tward, A.D.; Kostic, A.D.; Cibulskis, K.; Sivachenko, A.; Kryukov, G.V.; Lawrence, M.S.; Sougnez, C.; McKenna, A.; et al. The mutational landscape of head and neck squamous cell carcinoma. Science 2011, 333, 1157-1160. [CrossRef]

9. Agrawal, N.; Frederick, M.J.; Pickering, C.R.; Bettegowda, C.; Chang, K.; Li, R.J.; Fakhry, C.; Xie, T.-X.; Zhang, J.; Wang, J.; et al. Exome sequencing of head and neck squamous cell carcinoma reveals inactivating mutations in NOTCH1. Science 2011, 333, 1154-1157. [CrossRef]

10. Comprehensive genomic characterization of head and neck squamous cell carcinomas. Nature 2015, 517, 576-582. [CrossRef]

11. Chaturvedi, A.K.; Engels, E.A.; Pfeiffer, R.M.; Hernandez, B.Y.; Xiao, W.; Kim, E.; Jiang, B.; Goodman, M.T.; Sibug-Saber, M.; Cozen, W.; et al. Human papillomavirus and rising oropharyngeal cancer incidence in the United States. J. Clin. Oncol. 2011, 29, 4294-4301. [CrossRef]

12. Simard, E.P.; Ward, E.M.; Siegel, R.; Jemal, A. Cancers with increasing incidence trends in the United States: 1999 through 2008. CA Cancer J. Clin. 2012, 62, 118-128. [CrossRef]

13. Ellington, T.D.; Henley, S.J.; Senkomago, V.; O'Neil, M.E.; Wilson, R.J.; Singh, S.; Thomas, C.C.; Wu, M.; Richardson, L.C. Trends in Incidence of Cancers of the Oral Cavity and Pharynx-United States 2007-2016. MMWR. Morb. Mortal. Wkly. Rep. 2020, 69, 433-438. [CrossRef]

14. $\quad$ Ang, K.K.; Harris, J.; Wheeler, R.; Weber, R.; Rosenthal, D.I.; Nguyen-Tân, P.F.; Westra, W.H.; Chung, C.H.; Jordan, R.C.; Lu, C.; et al. Human papillomavirus and survival of patients with oropharyngeal cancer. Neww Engl. J. Med. 2010, 363, 24-35. [CrossRef]

15. Kimple, R.J.; Harari, P.M. The prognostic value of HPV in head and neck cancer patients undergoing postoperative chemoradiotherapy. Ann. Transl. Med. 2015, 3, S14. [CrossRef]

16. Cillo, A.R.; Kürten, C.H.L.; Tabib, T.; Qi, Z.; Onkar, S.S.; Wang, T.; Liu, A.; Duvvuri, U.; Kim, S.; Soose, R.J.; et al. Immune Landscape of Viral- and Carcinogen-Driven Head and Neck Cancer. Immunity 2020, 52, 183-199. [CrossRef]

17. Hashibe, M.; Brennan, P.; Benhamou, S.; Castellsague, X.; Chen, C.; Curado, M.P.; Dal Maso, L.; Daudt, A.W.; Fabianova, E.; Fernandez, L.; et al. Alcohol drinking in never users of tobacco, cigarette smoking in never drinkers, and the risk of head and neck cancer: Pooled analysis in the International Head and Neck Cancer Epidemiology Consortium. J. Natl. Cancer Inst. 2007, 99, 777-789. [CrossRef]

18. Jethwa, A.R.; Khariwala, S.S. Tobacco-related carcinogenesis in head and neck cancer. Cancer Metastasis Rev. 2017, 36, 411-423. [CrossRef] 
19. Di Credico, G.; Polesel, J.; Dal Maso, L.; Pauli, F.; Torelli, N.; Luce, D.; Radoï, L.; Matsuo, K.; Serraino, D.; Brennan, P.; et al. Alcohol drinking and head and neck cancer risk: The joint effect of intensity and duration. Br. J. Cancer 2020, 123, 1456-1463. [CrossRef]

20. Pfeifer, G.P.; Denissenko, M.F.; Olivier, M.; Tretyakova, N.; Hecht, S.S.; Hainaut, P. Tobacco smoke carcinogens, DNA damage and p53 mutations in smoking-associated cancers. Oncogene 2002, 21, 7435-7451. [CrossRef]

21. Khariwala, S.S.; Ma, B.; Ruszczak, C.; Carmella, S.G.; Lindgren, B.; Hatsukami, D.K.; Hecht, S.S.; Stepanov, I. High Level of Tobacco Carcinogen-Derived DNA Damage in Oral Cells Is an Independent Predictor of Oral/Head and Neck Cancer Risk in Smokers. Cancer Prev. Res. 2017, 10, 507-513. [CrossRef]

22. Slater, D.N. Dermatological applications of gene silencing RNA technology. Br. J. Derm. 2011, 164, 939. [CrossRef]

23. Hecht, S.S. Tobacco carcinogens, their biomarkers and tobacco-induced cancer. Nat. Rev. Cancer 2003, 3, 733-744. [CrossRef]

24. Gillison, M.L. Current topics in the epidemiology of oral cavity and oropharyngeal cancers. Head Neck 2007, 29, 779-792. [CrossRef]

25. Taioli, E. Gene-environment interaction in tobacco-related cancers. Carcinogenesis 2008, 29, 1467-1474. [CrossRef]

26. Ghosh, S.; Jagirdar, B.R. Synthesis of mesoporous iridium nanosponge: A highly active, thermally stable and efficient olefin hydrogenation catalyst. Dalton. Trans. 2017, 46, 11431-11439. [CrossRef]

27. Di Credico, G.; Edefonti, V.; Polesel, J.; Pauli, F.; Torelli, N.; Serraino, D.; Negri, E.; Luce, D.; Stucker, I.; Matsuo, K.; et al. Joint effects of intensity and duration of cigarette smoking on the risk of head and neck cancer: A bivariate spline model approach. Oral Oncol. 2019, 94, 47-57. [CrossRef]

28. Li, Y.C.; Cheng, A.J.; Lee, L.Y.; Huang, Y.C.; Chang, J.T. Multifaceted Mechanisms of Areca Nuts in Oral Carcinogenesis: The Molecular Pathology from Precancerous Condition to Malignant Transformation. J. Cancer 2019, 10, 4054-4062. [CrossRef]

29. Li, Y.C.; Chang, J.T.; Chiu, C.; Lu, Y.C.; Li, Y.L.; Chiang, C.H.; You, G.R.; Lee, L.Y.; Cheng, A.J. Areca nut contributes to oral malignancy through facilitating the conversion of cancer stem cells. Mol. Carcinog. 2016, 55, 1012-1023. [CrossRef] [PubMed]

30. Hashibe, M.; Brennan, P.; Chuang, S.C.; Boccia, S.; Castellsague, X.; Chen, C.; Curado, M.P.; Dal Maso, L.; Daudt, A.W.; Fabianova, E.; et al. Interaction between tobacco and alcohol use and the risk of head and neck cancer: Pooled analysis in the International Head and Neck Cancer Epidemiology Consortium. Cancer Epidemiol. Biomark. Prev. 2009, 18, 541-550. [CrossRef]

31. Caliri, A.W.; Tommasi, S.; Besaratinia, A. Relationships among smoking, oxidative stress, inflammation, macromolecular damage, and cancer. Mutat. Res. Rev. Mutat. Res. 2021, 787, 108365. [CrossRef] [PubMed]

32. D'Anna, C.; Cigna, D.; Costanzo, G.; Ferraro, M.; Siena, L.; Vitulo, P.; Gjomarkaj, M.; Pace, E. Cigarette smoke alters cell cycle and induces inflammation in lung fibroblasts. Life Sci. 2015, 126, 10-18. [CrossRef] [PubMed]

33. Sato, E.; Koyama, S.; Takamizawa, A.; Masubuchi, T.; Kubo, K.; Robbins, R.A.; Nagai, S.; Izumi, T. Smoke extract stimulates lung fibroblasts to release neutrophil and monocyte chemotactic activities. Am. J. Physiol. 1999, 277, L1149-L1157. [CrossRef] [PubMed]

34. Shen, Z.; Qin, X.; Yan, M.; Li, R.; Chen, G.; Zhang, J.; Chen, W. Cancer-associated fibroblasts promote cancer cell growth through a miR-7-RASSF2-PAR-4 axis in the tumor microenvironment. Oncotarget 2017, 8, 1290-1303. [CrossRef]

35. Curry, J.M.; Sprandio, J.; Cognetti, D.; Luginbuhl, A.; Bar-ad, V.; Pribitkin, E.; Tuluc, M. Tumor microenvironment in head and neck squamous cell carcinoma. Semin. Oncol. 2014, 41, 217-234. [CrossRef]

36. Rademakers, S.E.; Lok, J.; van der Kogel, A.J.; Bussink, J.; Kaanders, J.H. Metabolic markers in relation to hypoxia; staining patterns and colocalization of pimonidazole, HIF-1 $\alpha$, CAIX, LDH-5, GLUT-1, MCT1 and MCT4. BMC Cancer 2011, 11, 167. [CrossRef]

37. Domingo-Vidal, M.; Whitaker-Menezes, D.; Martos-Rus, C.; Tassone, P.; Snyder, C.M.; Tuluc, M.; Philp, N.; Curry, J.; MartinezOutschoorn, U. Cigarette Smoke Induces Metabolic Reprogramming of the Tumor Stroma in Head and Neck Squamous Cell Carcinoma. Mol. Cancer Res. 2019, 17, 1893-1909. [CrossRef]

38. Stämpfli, M.R.; Anderson, G.P. How cigarette smoke skews immune responses to promote infection, lung disease and cancer. Nat. Rev. Immunol. 2009, 9, 377-384. [CrossRef]

39. Clement, J.M.; Duan, F.; Srivastava, P.K. Smoking-induced immune deviation contributes to progression of bladder and other cancers. Oncoimmunology 2015, 4, e1019199. [CrossRef]

40. Kumar, S.; Torres, M.P.; Kaur, S.; Rachagani, S.; Joshi, S.; Johansson, S.L.; Momi, N.; Baine, M.J.; Gilling, C.E.; Smith, L.M.; et al. Smoking accelerates pancreatic cancer progression by promoting differentiation of MDSCs and inducing HB-EGF expression in macrophages. Oncogene 2015, 34, 2052-2060. [CrossRef]

41. Mandal, R.; Şenbabaoğlu, Y.; Desrichard, A.; Havel, J.J.; Dalin, M.G.; Riaz, N.; Lee, K.W.; Ganly, I.; Hakimi, A.A.; Chan, T.A.; et al. The head and neck cancer immune landscape and its immunotherapeutic implications. JCI Insight 2016, 1, e89829. [CrossRef]

42. Gao, L.; Wang, F.Q.; Li, H.M.; Yang, J.G.; Ren, J.G.; He, K.F.; Liu, B.; Zhang, W.; Zhao, Y.F. CCL2/EGF positive feedback loop between cancer cells and macrophages promotes cell migration and invasion in head and neck squamous cell carcinoma. Oncotarget 2016, 7, 87037-87051. [CrossRef]

43. Westrich, J.A.; Warren, C.J.; Pyeon, D. Evasion of Host Immune Defenses by Human Papillomavirus. Virus Res. 2016. [CrossRef]

44. Momi, N.; Kaur, S.; Rachagani, S.; Ganti, A.K.; Batra, S.K. Smoking and microRNA dysregulation: A cancerous combination. Trends Mol. Med. 2014, 20, 36-47. [CrossRef]

45. Krishnan, A.R.; Zheng, H.; Kwok, J.G.; Qu, Y.; Zou, A.E.; Korrapati, A.; Li, P.X.; Califano, J.A.; Hovell, M.F.; Wang-Rodriguez, J.; et al. A comprehensive study of smoking-specific microRNA alterations in head and neck squamous cell carcinoma. Oral Oncol. 2017, 72, 56-64. [CrossRef]

46. Bushati, N.; Cohen, S.M. microRNA functions. Annu. Rev. Cell Dev. Biol. 2007, 23, 175-205. [CrossRef] 
47. Doukas, S.G.; Vageli, D.P.; Lazopoulos, G.; Spandidos, D.A.; Sasaki, C.T.; Tsatsakis, A. The Effect of NNK, A Tobacco Smoke Carcinogen, on the miRNA and Mismatch DNA Repair Expression Profiles in Lung and Head and Neck Squamous Cancer Cells. Cells 2020, 9, 1031. [CrossRef]

48. Peng, H.Y.; Hsiao, J.R.; Chou, S.T.; Hsu, Y.M.; Wu, G.H.; Shieh, Y.S.; Shiah, S.G. MiR-944/CISH mediated inflammation via STAT3 is involved in oral cancer malignance by cigarette smoking. Neoplasia 2020, 22, 554-565. [CrossRef]

49. Zhang, T.; Zhu, X.; Sun, Q.; Qin, X.; Zhang, Z.; Feng, Y.; Yan, M.; Chen, W. Identification and Confirmation of the miR-30 Family as a Potential Central Player in Tobacco-Related Head and Neck Squamous Cell Carcinoma. Front. Oncol. 2021, 11, 616372. [CrossRef]

50. Kao, C.J.; Martiniez, A.; Shi, X.B.; Yang, J.; Evans, C.P.; Dobi, A.; deVere White, R.W.; Kung, H.J. miR-30 as a tumor suppressor connects EGF/Src signal to ERG and EMT. Oncogene 2014, 33, 2495-2503. [CrossRef]

51. Croset, M.; Pantano, F.; Kan, C.W.S.; Bonnelye, E.; Descotes, F.; Alix-Panabières, C.; Lecellier, C.H.; Bachelier, R.; Allioli, N.; Hong, S.S.; et al. miRNA-30 Family Members Inhibit Breast Cancer Invasion, Osteomimicry, and Bone Destruction by Directly Targeting Multiple Bone Metastasis-Associated Genes. Cancer Res. 2018, 78, 5259-5273. [CrossRef] [PubMed]

52. Saleh, A.D.; Cheng, H.; Martin, S.E.; Si, H.; Ormanoglu, P.; Carlson, S.; Clavijo, P.E.; Yang, X.; Das, R.; Cornelius, S.; et al. Integrated Genomic and Functional microRNA Analysis Identifies miR-30-5p as a Tumor Suppressor and Potential Therapeutic Nanomedicine in Head and Neck Cancer. Clin. Cancer Res. 2019, 25, 2860-2873. [CrossRef]

53. Akagi, K.; Li, J.; Broutian, T.R.; Padilla-Nash, H.; Xiao, W.; Jiang, B.; Rocco, J.W.; Teknos, T.N.; Kumar, B.; Wangsa, D.; et al. Genome-wide analysis of HPV integration in human cancers reveals recurrent, focal genomic instability. Genome Res. 2014, 24, 185-199. [CrossRef]

54. Kalantari, M.; Lee, D.; Calleja-Macias, I.E.; Lambert, P.F.; Bernard, H.U. Effects of cellular differentiation, chromosomal integration and 5-aza-2'-deoxycytidine treatment on human papillomavirus-16 DNA methylation in cultured cell lines. Virology 2008, 374, 292-303. [CrossRef]

55. Dürst, M.; Kleinheinz, A.; Hotz, M.; Gissmann, L. The physical state of human papillomavirus type 16 DNA in benign and malignant genital tumours. J. Gen. Virol. 1985, 66, 1515-1522. [CrossRef]

56. Jeon, S.; Lambert, P.F. Integration of human papillomavirus type 16 DNA into the human genome leads to increased stability of E6 and E7 mRNAs: Implications for cervical carcinogenesis. Proc. Natl. Acad. Sci. USA 1995, 92, 1654-1658. [CrossRef]

57. Bernard, B.A.; Bailly, C.; Lenoir, M.C.; Darmon, M.; Thierry, F.; Yaniv, M. The human papillomavirus type 18 (HPV18) E2 gene product is a repressor of the HPV18 regulatory region in human keratinocytes. J. Virol. 1989, 63, 4317-4324. [CrossRef]

58. Romanczuk, H.; Thierry, F.; Howley, P.M. Mutational analysis of cis elements involved in E2 modulation of human papillomavirus type 16 P97 and type 18 P105 promoters. J. Virol. 1990, 64, 2849-2859. [CrossRef]

59. Mesri, E.A.; Feitelson, M.A.; Munger, K. Human viral oncogenesis: A cancer hallmarks analysis. Cell Host Microbe 2014, 15, 266-282. [CrossRef]

60. Parfenov, M.; Pedamallu, C.S.; Gehlenborg, N.; Freeman, S.S.; Danilova, L.; Bristow, C.A.; Lee, S.; Hadjipanayis, A.G.; Ivanova, E.V.; Wilkerson, M.D.; et al. Characterization of HPV and host genome interactions in primary head and neck cancers. Proc. Natl. Acad. Sci. USA 2014, 111, 15544-15549. [CrossRef]

61. Ren, S.; Gaykalova, D.A.; Guo, T.; Favorov, A.V.; Fertig, E.J.; Tamayo, P.; Callejas-Valera, J.L.; Allevato, M.; Gilardi, M.; Santos, J.; et al. HPV E2, E4, E5 drive alternative carcinogenic pathways in HPV positive cancers. Oncogene 2020, 39, 6327-6339. [CrossRef] [PubMed]

62. Zhou, G.; Liu, Z.; Myers, J.N. TP53 Mutations in Head and Neck Squamous Cell Carcinoma and Their Impact on Disease Progression and Treatment Response. J. Cell Biochem. 2016, 117, 2682-2692. [CrossRef] [PubMed]

63. Smeets, S.J.; Braakhuis, B.J.; Abbas, S.; Snijders, P.J.; Ylstra, B.; van de Wiel, M.A.; Meijer, G.A.; Leemans, C.R.; Brakenhoff, R.H. Genome-wide DNA copy number alterations in head and neck squamous cell carcinomas with or without oncogene-expressing human papillomavirus. Oncogene 2006, 25, 2558-2564. [CrossRef] [PubMed]

64. Roman, E.; Meza-Zepeda, L.A.; Kresse, S.H.; Myklebost, O.; Vasstrand, E.N.; Ibrahim, S.O. Chromosomal aberrations in head and neck squamous cell carcinomas in Norwegian and Sudanese populations by array comparative genomic hybridization. Oncol. Rep. 2008, 20, 825-843. [CrossRef] [PubMed]

65. Kelley, D.Z.; Flam, E.L.; Izumchenko, E.; Danilova, L.V.; Wulf, H.A.; Guo, T.; Singman, D.A.; Afsari, B.; Skaist, A.M.; Considine, M.; et al. Integrated Analysis of Whole-Genome ChIP-Seq and RNA-Seq Data of Primary Head and Neck Tumor Samples Associates HPV Integration Sites with Open Chromatin Marks. Cancer Res. 2017, 77, 6538-6550. [CrossRef]

66. Aldersley, J.; Lorenz, D.R.; Mouw, K.W.; D’Andrea, A.D.; Gabuzda, D. Genomic Landscape of Primary and Recurrent Anal Squamous Cell Carcinomas in Relation to HPV Integration, Copy-Number Variation, and DNA Damage Response Genes. Mol. Cancer Res. 2021, 19, 1308-1321. [CrossRef]

67. den Boon, J.A.; Pyeon, D.; Wang, S.S.; Horswill, M.; Schiffman, M.; Sherman, M.; Zuna, R.E.; Wang, Z.; Hewitt, S.M.; Pearson, R.; et al. Molecular transitions from papillomavirus infection to cervical precancer and cancer: Role of stromal estrogen receptor signaling. Proc. Natl. Acad. Sci. USA 2015, 112, E3255-E3264. [CrossRef]

68. Aggarwal, C.; Cohen, R.B.; Morrow, M.P.; Kraynyak, K.A.; Sylvester, A.J.; Knoblock, D.M.; Bauml, J.M.; Weinstein, G.S.; Lin, A.; Boyer, J.; et al. Immunotherapy Targeting HPV16/18 Generates Potent Immune Responses in HPV-Associated Head and Neck Cancer. Clin. Cancer Res. 2019, 25, 110-124. [CrossRef] 
69. Faden, D.L.; Ding, F.; Lin, Y.; Zhai, S.; Kuo, F.; Chan, T.A.; Morris, L.G.; Ferris, R.L. APOBEC mutagenesis is tightly linked to the immune landscape and immunotherapy biomarkers in head and neck squamous cell carcinoma. Oral Oncol. 2019, 96, 140-147. [CrossRef]

70. Warren, C.J.; Xu, T.; Guo, K.; Griffin, L.M.; Westrich, J.a.; Lee, D.; Lambert, P.F.; Santiago, M.L.; Pyeon, D. APOBEC3A Functions as a Restriction Factor of Human Papillomavirus. J. Virol. 2015, 89, 688-702. [CrossRef]

71. Leemans, C.R.; Snijders, P.J.F.; Brakenhoff, R.H. The molecular landscape of head and neck cancer. Nat. Rev. Cancer 2018, 18, 269-282. [CrossRef]

72. Ferris, R.L.; Blumenschein, G., Jr.; Fayette, J.; Guigay, J.; Colevas, A.D.; Licitra, L.; Harrington, K.; Kasper, S.; Vokes, E.E.; Even, C.; et al. Nivolumab for Recurrent Squamous-Cell Carcinoma of the Head and Neck. N. Engl. J. Med 2016, 375, 1856-1867. [CrossRef]

73. Sacco, A.G.; Chen, R.; Worden, F.P.; Wong, D.J.L.; Adkins, D.; Swiecicki, P.; Chai-Ho, W.; Oppelt, P.; Ghosh, D.; Bykowski, J.; et al. Pembrolizumab plus cetuximab in patients with recurrent or metastatic head and neck squamous cell carcinoma: An open-label, multi-arm, non-randomised, multicentre, phase 2 trial. Lancet Oncol. 2021, 22, 883-892. [CrossRef]

74. Van der Leun, A.M.; Thommen, D.S.; Schumacher, T.N. CD8(+) T cell states in human cancer: Insights from single-cell analysis. Nat. Rev. Cancer 2020, 20, 218-232. [CrossRef]

75. Van Kempen, P.M.; Noorlag, R.; Swartz, J.E.; Bovenschen, N.; Braunius, W.W.; Vermeulen, J.F.; Van Cann, E.M.; Grolman, W.; Willems, S.M. Oropharyngeal squamous cell carcinomas differentially express granzyme inhibitors. Cancer Immunol. Immunother. 2016, 65, 575-585. [CrossRef]

76. Solomon, B.; Young, R.J.; Bressel, M.; Urban, D.; Hendry, S.; Thai, A.; Angel, C.; Haddad, A.; Kowanetz, M.; Fua, T.; et al. Prognostic Significance of PD-L1(+) and CD8(+) Immune Cells in HPV(+) Oropharyngeal Squamous Cell Carcinoma. Cancer Immunol. Res. 2018, 6, 295-304. [CrossRef]

77. Welters, M.J.P.; Ma, W.; Santegoets, S.; Goedemans, R.; Ehsan, I.; Jordanova, E.S.; van Ham, V.J.; van Unen, V.; Koning, F.; van Egmond, S.I.; et al. Intratumoral HPV16-Specific T Cells Constitute a Type I-Oriented Tumor Microenvironment to Improve Survival in HPV16-Driven Oropharyngeal Cancer. Clin. Cancer Res. 2018, 24, 634-647. [CrossRef]

78. Nordfors, C.; Grün, N.; Tertipis, N.; Ährlund-Richter, A.; Haeggblom, L.; Sivars, L.; Du, J.; Nyberg, T.; Marklund, L.; MunckWikland, E.; et al. CD8+ and CD4+ tumour infiltrating lymphocytes in relation to human papillomavirus status and clinical outcome in tonsillar and base of tongue squamous cell carcinoma. Eur. J. Cancer. 2013, 49, 2522-2530. [CrossRef]

79. So, Y.K.; Byeon, S.J.; Ku, B.M.; Ko, Y.H.; Ahn, M.J.; Son, Y.I.; Chung, M.K. An increase of CD8(+) T cell infiltration following recurrence is a good prognosticator in HNSCC. Sci. Rep. 2020, 10, 20059. [CrossRef]

80. Badoual, C.; Hans, S.; Merillon, N.; Van Ryswick, C.; Ravel, P.; Benhamouda, N.; Levionnois, E.; Nizard, M.; Si-Mohamed, A.; Besnier, N.; et al. PD-1-expressing tumor-infiltrating T cells are a favorable prognostic biomarker in HPV-associated head and neck cancer. Cancer Res. 2013, 73, 128-138. [CrossRef]

81. Kansy, B.A.; Concha-Benavente, F.; Srivastava, R.M.; Jie, H.B.; Shayan, G.; Lei, Y.; Moskovitz, J.; Moy, J.; Li, J.; Brandau, S.; et al. PD-1 Status in CD8(+) T Cells Associates with Survival and Anti-PD-1 Therapeutic Outcomes in Head and Neck Cancer. Cancer Res. 2017, 77, 6353-6364. [CrossRef]

82. Outh-Gauer, S.; Morini, A.; Tartour, E.; Lépine, C.; Jung, A.C.; Badoual, C. The Microenvironment of Head and Neck Cancers: Papillomavirus Involvement and Potential Impact of Immunomodulatory Treatments. Head Neck Pathol. 2020, 14, 330-340. [CrossRef]

83. Hegde, P.S.; Chen, D.S. Top 10 Challenges in Cancer Immunotherapy. Immunity 2020, 52, 17-35. [CrossRef]

84. Hegde, P.S.; Karanikas, V.; Evers, S. The Where, the When, and the How of Immune Monitoring for Cancer Immunotherapies in the Era of Checkpoint Inhibition. Clin. Cancer Res. 2016, 22, 1865-1874. [CrossRef]

85. Bhatt, K.H.; Neller, M.A.; Srihari, S.; Crooks, P.; Lekieffre, L.; Aftab, B.T.; Liu, H.; Smith, C.; Kenny, L.; Porceddu, S.; et al. Profiling HPV-16-specific T cell responses reveals broad antigen reactivities in oropharyngeal cancer patients. J. Exp. Med. 2020, 217. [CrossRef]

86. Albers, A.; Abe, K.; Hunt, J.; Wang, J.; Lopez-Albaitero, A.; Schaefer, C.; Gooding, W.; Whiteside, T.L.; Ferrone, S.; DeLeo, A.; et al. Antitumor activity of human papillomavirus type 16 E7-specific T cells against virally infected squamous cell carcinoma of the head and neck. Cancer Res. 2005, 65, 11146-11155. [CrossRef]

87. Sanchez-Canteli, M.; Granda-Díaz, R.; Del Rio-Ibisate, N.; Allonca, E.; López-Alvarez, F.; Agorreta, J.; Garmendia, I.; Montuenga, L.M.; García-Pedrero, J.M.; Rodrigo, J.P. PD-L1 expression correlates with tumor-infiltrating lymphocytes and better prognosis in patients with HPV-negative head and neck squamous cell carcinomas. Cancer Immunol. Immunother. 2020, 69, 2089-2100. [CrossRef]

88. Balermpas, P.; Rödel, F.; Krause, M.; Linge, A.; Lohaus, F.; Baumann, M.; Tinhofer, I.; Budach, V.; Sak, A.; Stuschke, M.; et al. The PD-1/PD-L1 axis and human papilloma virus in patients with head and neck cancer after adjuvant chemoradiotherapy: A multicentre study of the German Cancer Consortium Radiation Oncology Group (DKTK-ROG). Int. J. Cancer 2017, 141, 594-603. [CrossRef]

89. Wuerdemann, N.; Gültekin, S.E.; Pütz, K.; Wittekindt, C.; Huebbers, C.U.; Sharma, S.J.; Eckel, H.; Schubotz, A.B.; Gattenlöhner, S.; Büttner, R.; et al. PD-L1 Expression and a High Tumor Infiltrate of CD8+ Lymphocytes Predict Outcome in Patients with Oropharyngeal Squamous Cells Carcinoma. Int. J. Mol. Sci. 2020, 21, 5228. [CrossRef]

90. Gameiro, S.F.; Ghasemi, F.; Barrett, J.W.; Koropatnick, J.; Nichols, A.C.; Mymryk, J.S.; Maleki Vareki, S. Treatment-naïve HPV+ head and neck cancers display a T-cell-inflamed phenotype distinct from their HPV-counterparts that has implications for immunotherapy. Oncoimmunology 2018, 7, e1498439. [CrossRef] 
91. Stevanović, S.; Pasetto, A.; Helman, S.R.; Gartner, J.J.; Prickett, T.D.; Howie, B.; Robins, H.S.; Robbins, P.F.; Klebanoff, C.A.; Rosenberg, S.A.; et al. Landscape of immunogenic tumor antigens in successful immunotherapy of virally induced epithelial cancer. Science 2017, 356, 200-205. [CrossRef] [PubMed]

92. Cicchini, L.; Blumhagen, R.Z.; Westrich, J.A.; Myers, M.E.; Warren, C.J.; Siska, C.; Raben, D.; Kechris, K.J.; Pyeon, D. High-Risk Human Papillomavirus E7 Alters Host DNA Methylome and Represses HLA-E Expression in Human Keratinocytes. Sci. Rep. 2017, 7, 3633. [CrossRef] [PubMed]

93. Westrich, J.A.; Vermeer, D.W.; Silva, A.; Bonney, S.; Berger, J.N.; Cicchini, L.; Greer, R.O.; Song, J.I.; Raben, D.; Slansky, J.E.; et al. CXCL14 suppresses human papillomavirus-associated head and neck cancer through antigen-specific CD8(+) T-cell responses by upregulating MHC-I expression. Oncogene 2019, 38, 7166-7180. [CrossRef] [PubMed]

94. Gameiro, S.F.; Zhang, A.; Ghasemi, F.; Barrett, J.W.; Nichols, A.C.; Mymryk, J.S. Analysis of Class I Major Histocompatibility Complex Gene Transcription in Human Tumors Caused by Human Papillomavirus Infection. Viruses 2017, 9, 252. [CrossRef] [PubMed]

95. Chen, X.; Yan, B.; Lou, H.; Shen, Z.; Tong, F.; Zhai, A.; Wei, L.; Zhang, F. Immunological network analysis in HPV associated head and neck squamous cancer and implications for disease prognosis. Mol. Immunol. 2018, 96, 28-36. [CrossRef]

96. Ruffin, A.T.; Cillo, A.R.; Tabib, T.; Liu, A.; Onkar, S.; Kunning, S.R.; Lampenfeld, C.; Atiya, H.I.; Abecassis, I.; Kürten, C.H.L.; et al. B cell signatures and tertiary lymphoid structures contribute to outcome in head and neck squamous cell carcinoma. Nat. Commun. 2021, 12, 3349. [CrossRef]

97. Hladíková, K.; Koucký, V.; Bouček, J.; Laco, J.; Grega, M.; Hodek, M.; Zábrodský, M.; Vošmik, M.; Rozkošová, K.; Vošmiková, H.; et al. Tumor-infiltrating B cells affect the progression of oropharyngeal squamous cell carcinoma via cell-to-cell interactions with CD8(+) T cells. J. Immunother. Cancer 2019, 7, 261. [CrossRef]

98. Wood, O.; Woo, J.; Seumois, G.; Savelyeva, N.; McCann, K.J.; Singh, D.; Jones, T.; Peel, L.; Breen, M.S.; Ward, M.; et al. Gene expression analysis of TIL rich HPV-driven head and neck tumors reveals a distinct B-cell signature when compared to HPV independent tumors. Oncotarget 2016, 7, 56781-56797. [CrossRef]

99. Snietura, M.; Brewczynski, A.; Kopec, A.; Rutkowski, T. Infiltrates of M2-Like Tumour-Associated Macrophages Are Adverse Prognostic Factor in Patients with Human Papillomavirus-Negative but Not in Human Papillomavirus-Positive Oropharyngeal Squamous Cell Carcinoma. Pathobiology 2020, 87, 75-86. [CrossRef]

100. Santegoets, S.J.; Duurland, C.L.; Jordanova, E.J.; van Ham, V.J.; Ehsan, I.; Loof, N.M.; Narang, V.; Dutertre, C.A.; Ginhoux, F.; van Egmond, S.L.; et al. CD163(+) cytokine-producing CDC2 stimulate intratumoral type $1 \mathrm{~T}$ cell responses in HPV16-induced oropharyngeal cancer. J. Immunother. Cancer 2020, 8. [CrossRef]

101. Koucký, V.; Hladíková, K.; Táborská, E.; Bouček, J.; Grega, M.; Špíšek, R.; Fialová, A. The cytokine milieu compromises functional capacity of tumor-infiltrating plasmacytoid dendritic cells in HPV-negative but not in HPV-positive HNSCC. Cancer Immunol. Immunother. 2021, 70, 2545-2557. [CrossRef]

102. Johnson-Obaseki, S.; Caulley, L.; Corsten, M.; Liu, G.; Dimitroulakos, J.; Goldstein, D.; Irish, J.; Rider, J. C-reactive Protein in HPV-Positive and HPV-Negative Oropharyngeal Cancer. Otolaryngol. Head Neck Surg. 2019, 160, 494-501. [CrossRef]

103. Seiwert, T.Y.; Burtness, B.; Mehra, R.; Weiss, J.; Berger, R.; Eder, J.P.; Heath, K.; McClanahan, T.; Lunceford, J.; Gause, C.; et al. Safety and clinical activity of pembrolizumab for treatment of recurrent or metastatic squamous cell carcinoma of the head and neck (KEYNOTE-012): An open-label, multicentre, phase 1b trial. Lancet Oncol. 2016, 17, 956-965. [CrossRef]

104. Bauml, J.; Seiwert, T.Y.; Pfister, D.G.; Worden, F.; Liu, S.V.; Gilbert, J.; Saba, N.F.; Weiss, J.; Wirth, L.; Sukari, A.; et al. Pembrolizumab for Platinum- and Cetuximab-Refractory Head and Neck Cancer: Results From a Single-Arm, Phase II Study. J. Clin. Oncol. 2017, 35, 1542-1549. [CrossRef]

105. Peterson, J.; Garges, S.; Giovanni, M.; McInnes, P.; Wang, L.; Schloss, J.A.; Bonazzi, V.; McEwen, J.E.; Wetterstrand, K.A.; Deal, C.; et al. The NIH Human Microbiome Project. Genome Res. 2009, 19, 2317-2323. [CrossRef]

106. Rajasekaran, K.; Carey, R.M.; Lin, X.; Seckar, T.D.; Wei, Z.; Chorath, K.; Newman, J.G.; O'Malley, B.W.; Weinstein, G.S.; Feldman, M.D.; et al. The microbiome of HPV-positive tonsil squamous cell carcinoma and neck metastasis. Oral Oncol. 2021, 117, 105305. [CrossRef]

107. Burr, A.H.P.; Bhattacharjee, A.; Hand, T.W. Nutritional Modulation of the Microbiome and Immune Response. J. Immunol. 2020, 205, 1479-1487. [CrossRef]

108. Chung, H.; Pamp, S.J.; Hill, J.A.; Surana, N.K.; Edelman, S.M.; Troy, E.B.; Reading, N.C.; Villablanca, E.J.; Wang, S.; Mora, J.R.; et al. Gut immune maturation depends on colonization with a host-specific microbiota. Cell 2012, 149, 1578-1593. [CrossRef]

109. Fonseca, D.M.; Hand, T.W.; Han, S.J.; Gerner, M.Y.; Glatman Zaretsky, A.; Byrd, A.L.; Harrison, O.J.; Ortiz, A.M.; Quinones, M.; Trinchieri, G.; et al. Microbiota-Dependent Sequelae of Acute Infection Compromise Tissue-Specific Immunity. Cell 2015, 163, 354-366. [CrossRef]

110. Zhang, L.; Liu, Y.; Zheng, H.J.; Zhang, C.P. The Oral Microbiota May Have Influence on Oral Cancer. Front. Cell Infect. Microbiol. 2019, 9, 476. [CrossRef]

111. Guerrero-Preston, R.; Godoy-Vitorino, F.; Jedlicka, A.; Rodríguez-Hilario, A.; González, H.; Bondy, J.; Lawson, F.; Folawiyo, O.; Michailidi, C.; Dziedzic, A.; et al. 16S rRNA amplicon sequencing identifies microbiota associated with oral cancer, human papilloma virus infection and surgical treatment. Oncotarget 2016, 7, 51320-51334. [CrossRef]

112. Schmidt, B.L.; Kuczynski, J.; Bhattacharya, A.; Huey, B.; Corby, P.M.; Queiroz, E.L.; Nightingale, K.; Kerr, A.R.; de Lacure, M.D.; Veeramachaneni, R.; et al. Changes in abundance of oral microbiota associated with oral cancer. PLoS ONE 2014, 9, e98741. [CrossRef] 
113. Hayes, R.B.; Ahn, J.; Fan, X.; Peters, B.A.; Ma, Y.; Yang, L.; Agalliu, I.; Burk, R.D.; Ganly, I.; Purdue, M.P.; et al. Association of Oral Microbiome With Risk for Incident Head and Neck Squamous Cell Cancer. JAMA Oncol. 2018, 4, 358-365. [CrossRef]

114. Ganly, I.; Yang, L.; Giese, R.A.; Hao, Y.; Nossa, C.W.; Morris, L.G.T.; Rosenthal, M.; Migliacci, J.; Kelly, D.; Tseng, W.; et al. Periodontal pathogens are a risk factor of oral cavity squamous cell carcinoma, independent of tobacco and alcohol and human papillomavirus. Int. J. Cancer. 2019, 145, 775-784. [CrossRef]

115. Sharma, A.K.; DeBusk, W.T.; Stepanov, I.; Gomez, A.; Khariwala, S.S. Oral Microbiome Profiling in Smokers with and without Head and Neck Cancer Reveals Variations Between Health and Disease. Cancer Prev. Res. 2020, 13, 463-474. [CrossRef]

116. Neuzillet, C.; Marchais, M.; Vacher, S.; Hilmi, M.; Schnitzler, A.; Meseure, D.; Leclere, R.; Lecerf, C.; Dubot, C.; Jeannot, E.; et al. Prognostic value of intratumoral Fusobacterium nucleatum and association with immune-related gene expression in oral squamous cell carcinoma patients. Sci. Rep. 2021, 11, 7870. [CrossRef]

117. Yamamura, K.; Baba, Y.; Nakagawa, S.; Mima, K.; Miyake, K.; Nakamura, K.; Sawayama, H.; Kinoshita, K.; Ishimoto, T.; Iwatsuki, M.; et al. Human Microbiome Fusobacterium Nucleatum in Esophageal Cancer Tissue Is Associated with Prognosis. Clin. Cancer Res. 2016, 22, 5574-5581. [CrossRef]

118. Suez, J.; Zmora, N.; Zilberman-Schapira, G.; Mor, U.; Dori-Bachash, M.; Bashiardes, S.; Zur, M.; Regev-Lehavi, D.; Ben-Zeev Brik, R.; Federici, S.; et al. Post-Antibiotic Gut Mucosal Microbiome Reconstitution Is Impaired by Probiotics and Improved by Autologous FMT. Cell 2018, 174, 1406-1423. [CrossRef]

119. Shi, Y.; Zhao, X.; Zhao, J.; Zhang, H.; Zhai, Q.; Narbad, A.; Chen, W. A mixture of Lactobacillus species isolated from traditional fermented foods promote recovery from antibiotic-induced intestinal disruption in mice. J. Appl. Microbiol. 2018, 124, 842-854. [CrossRef] [PubMed]

120. Fan, X.; Peters, B.A.; Jacobs, E.J.; Gapstur, S.M.; Purdue, M.P.; Freedman, N.D.; Alekseyenko, A.V.; Wu, J.; Yang, L.; Pei, Z.; et al. Drinking alcohol is associated with variation in the human oral microbiome in a large study of American adults. Microbiome 2018, 6, 59. [CrossRef]

121. Orlandi, E.; Iacovelli, N.A.; Tombolini, V.; Rancati, T.; Polimeni, A.; De Cecco, L.; Valdagni, R.; De Felice, F. Potential role of microbiome in oncogenesis, outcome prediction and therapeutic targeting for head and neck cancer. Oral Oncol. 2019, 99, 104453. [CrossRef] [PubMed]

122. Bronzato, J.D.; Bomfim, R.A.; Edwards, D.H.; Crouch, D.; Hector, M.P.; Gomes, B. Detection of Fusobacterium in oral and head and neck cancer samples: A systematic review and meta-analysis. Arch. Oral Biol. 2020, 112, 104669. [CrossRef] [PubMed]

123. Healy, C.M.; Moran, G.P. The microbiome and oral cancer: More questions than answers. Oral Oncol. 2019, 89, 30-33. [CrossRef] [PubMed]

124. Chen, Z.; Wong, P.Y.; Ng, C.W.K.; Lan, L.; Fung, S.; Li, J.W.; Cai, L.; Lei, P.; Mou, Q.; Wong, S.H.; et al. The Intersection between Oral Microbiota, Host Gene Methylation and Patient Outcomes in Head and Neck Squamous Cell Carcinoma. Cancers 2020, 12, 3425. [CrossRef]

125. Sabatini, M.E.; Chiocca, S. Human papillomavirus as a driver of head and neck cancers. Br. J. Cancer. 2020, 122, 306-314. [CrossRef]

126. Chatterjee, S.; Do Kang, S.; Alam, S.; Salzberg, A.C.; Milici, J.; van der Burg, S.H.; Freeman, W.; Meyers, C. Tissue-Specific Gene Expression during Productive Human Papillomavirus 16 Infection of Cervical, Foreskin, and Tonsil Epithelium. J. Virol. 2019, 93. [CrossRef]

127. Gazzaz, M.J.; Jeffery, C.; O’Connell, D.; Harris, J.; Seikaly, H.; Biron, V. Association of human papillomavirus related squamous cell carcinomas of the oropharynx and cervix. Papillomavirus Res. 2019, 8, 100188. [CrossRef]

128. Sindrewicz, K.; Kędzierska-Kapuza, K.; Jaworowska, E.; Ciechanowski, K. Prevalence of Human Papillomavirus Infection in the Head and Neck Area of Patients After Kidney Transplantation Treated With Immunosuppressive Therapy. Transpl. Proc. 2020, 52, 2388-2393. [CrossRef]

129. Freedman, R.L.; Sibley, H.; Williams, A.M.; Chang, S.S. Race, not socioeconomic disparities, correlates with survival in human papillomavirus-negative oropharyngeal cancer: A retrospective study. Am. J. Otolaryngol. 2021, 42, 102816. [CrossRef]

130. Sheth, S.; Farquhar, D.R.; Lenze, N.R.; Mazul, A.; Brennan, P.; Anantharaman, D.; Abedi-Ardekani, B.; Zevallos, J.P.; Hayes, D.N.; Olshan, F. Decreased overall survival in black patients with HPV-associated oropharyngeal cancer. Am. J. Otolaryngol. 2021, 42, 102780. [CrossRef]

131. Mazul, A.L.; Naik, A.N.; Zhan, K.Y.; Stepan, K.O.; Old, M.O.; Kang, S.Y.; Nakken, E.R.; Puram, S.V. Gender and race interact to influence survival disparities in head and neck cancer. Oral Oncol. 2021, 112, 105093. [CrossRef]

132. Stein, E.; Lenze, N.R.; Yarbrough, W.G.; Hayes, D.N.; Mazul, A.; Sheth, S. Systematic review and meta-analysis of racial survival disparities among oropharyngeal cancer cases by HPV status. Head Neck 2020, 42, 2985-3001. [CrossRef]

133. Fakhry, C.; Westra, W.H.; Wang, S.J.; van Zante, A.; Zhang, Y.; Rettig, E.; Yin, L.X.; Ryan, W.R.; Ha, P.K.; Wentz, A.; et al. The prognostic role of sex, race, and human papillomavirus in oropharyngeal and nonoropharyngeal head and neck squamous cell cancer. Cancer 2017, 123, 1566-1575. [CrossRef]

134. Mazul, A.L.; Colditz, G.A.; Zevallos, J.P. Factors associated with HPV testing in oropharyngeal cancer in the National Cancer Data Base from 2013 to 2015. Oral Oncol. 2020, 104, 104609. [CrossRef]

135. deJong, R.J.B.; Brandwein-Gensler, M.; Brizel, D.M.; Califano, J.A.; Amy, Y.; Chen, M.M.P.H.; Colevas, A.D.; Edge, S.B.; Fury, M.; Ghossein, R.A.; et al. AJCC Cancer Staging System; American College of Surgeons: Chicago, IL, USA, 2017.

136. Pfister, D.G.; Spencer, S.; Adelstein, D.; Adkins, D.; Anzai, Y.; Brizel, D.M.; Bruce, J.Y.; Busse, P.M.; Caudell, J.J.; Cmelak, A.J.; et al. Head and Neck Cancers, Version 2.2020, NCCN Clinical Practice Guidelines in Oncology. J. Natl. Compr. Cancer Netw. 2020, 18, 873-898. [CrossRef] 
137. Lacas, B.; Carmel, A.; Landais, C.; Wong, S.J.; Licitra, L.; Tobias, J.S.; Burtness, B.; Ghi, M.G.; Cohen, E.E.W.; Grau, C.; et al. Meta-analysis of chemotherapy in head and neck cancer (MACH-NC): An update on 107 randomized trials and 19,805 patients, on behalf of MACH-NC Group. Radiother. Oncol. 2021, 156, 281-293. [CrossRef]

138. Heiduschka, G.; Grah, A.; Oberndorfer, F.; Kadletz, L.; Altorjai, G.; Kornek, G.; Wrba, F.; Thurnher, D.; Selzer, E. Improved survival in HPV/p16-positive oropharyngeal cancer patients treated with postoperative radiotherapy. Strahlenther. Onkol. 2015, 191, 209-216. [CrossRef]

139. Viros Porcuna, D.; Pollan Guisasola, C.; Viña Soria, C.; Cirauqui Cirauqui, B.; Pardo Muñoz, L.; Collurá, F.; Mesia Nin, R. Transoral robotic surgery for squamous cell carcinoma of the oropharynx in a primarily human papillomavirus-negative patient population. Clin. Transl. Oncol. 2020, 22, 1303-1311. [CrossRef]

140. Sload, R.; Silver, N.; Jawad, B.A.; Gross, N.D. The Role of Transoral Robotic Surgery in the Management of HPV Negative Oropharyngeal Squamous Cell Carcinoma. Curr. Oncol. Rep. 2016, 18, 53. [CrossRef]

141. Zhan, K.Y.; Puram, S.V.; Li, M.M.; Silverman, D.A.; Agrawal, A.A.; Ozer, E.; Old, M.O.; Carrau, R.L.; Rocco, J.W.; Higgins, K.M.; et al. National treatment trends in human papillomavirus-positive oropharyngeal squamous cell carcinoma. Cancer 2020, 126, 1295-1305. [CrossRef]

142. Rubek, N.; Channir, H.I.; Charabi, B.W.; Lajer, C.B.; Kiss, K.; Nielsen, H.U.; Bentzen, J.; Friborg, J.; von Buchwald, C. Primary transoral robotic surgery with concurrent neck dissection for early stage oropharyngeal squamous cell carcinoma implemented at a Danish head and neck cancer center: A phase II trial on feasibility and tumour margin status. Eur. Arch. Otorhinolaryngol. 2017, 274, 2229-2237. [CrossRef]

143. Høxbroe Michaelsen, S.; Grønhøj, C.; Høxbroe Michaelsen, J.; Friborg, J.; von Buchwald, C. Quality of life in survivors of oropharyngeal cancer: A systematic review and meta-analysis of 1366 patients. Eur. J. Cancer 2017, 78, 91-102. [CrossRef]

144. Nichols, D.S.; Zhao, J.; Boyce, B.J.; Amdur, R.; Mendenhall, W.M.; Danan, D.; Hitchcock, K.; Ning, K.; Keyes, K.; Lee, J.H.; et al. $\mathrm{HPV} / \mathrm{p}$ 16-positive oropharyngeal cancer treated with transoral robotic surgery: The roles of margins, extra-nodal extension and adjuvant treatment. Am. J. Otolaryngol. 2021, 42, 102793. [CrossRef]

145. Schwartz, S.R.; Yueh, B.; McDougall, J.K.; Daling, J.R.; Schwartz, S.M. Human papillomavirus infection and survival in oral squamous cell cancer: A population-based study. Otolaryngol. Head Neck Surg. 2001, 125, 1-9. [CrossRef]

146. Licitra, L.; Perrone, F.; Bossi, P.; Suardi, S.; Mariani, L.; Artusi, R.; Oggionni, M.; Rossini, C.; Cantù, G.; Squadrelli, M.; et al. High-risk human papillomavirus affects prognosis in patients with surgically treated oropharyngeal squamous cell carcinoma. $J$. Clin. Oncol. 2006, 24, 5630-5636. [CrossRef]

147. Cmelak, A.; Dietrich, M.S.; Li, S.; Ridner, S.; Forastiere, A.; Burtness, B.A.; Cella, D.; Murphy, B.A. ECOG-ACRIN 2399: Analysis of patient related outcomes after Chemoradiation for locally advanced head and neck Cancer. Cancers Head Neck 2020, 5, 12. [CrossRef]

148. Fakhry, C.; Westra, W.H.; Li, S.; Cmelak, A.; Ridge, J.A.; Pinto, H.; Forastiere, A.; Gillison, M.L. Improved survival of patients with human papillomavirus-positive head and neck squamous cell carcinoma in a prospective clinical trial. J. Natl. Cancer Inst. 2008, 100, 261-269. [CrossRef]

149. Rischin, D.; Young, R.J.; Fisher, R.; Fox, S.B.; Le, Q.-T.; Peters, L.J.; Solomon, B.; Choi, J.; O'Sullivan, B.; Kenny, L.M.; et al. Prognostic significance of p16INK4A and human papillomavirus in patients with oropharyngeal cancer treated on TROG 02.02 phase III trial. J. Clin. Oncol. 2010, 28, 4142-4148. [CrossRef]

150. Posner, M.R.; Lorch, J.H.; Goloubeva, O.; Tan, M.; Schumaker, L.M.; Sarlis, N.J.; Haddad, R.I.; Cullen, K.J. Survival and human papillomavirus in oropharynx cancer in TAX 324: A subset analysis from an international phase III trial. Ann. Oncol. 2011, 22, 1071-1077. [CrossRef]

151. O'Sullivan, B.; Huang, S.H.; Su, J.; Garden, A.S.; Sturgis, E.M.; Dahlstrom, K.; Lee, N.; Riaz, N.; Pei, X.; Koyfman, S.A.; et al. Development and validation of a staging system for HPV-related oropharyngeal cancer by the International Collaboration on Oropharyngeal cancer Network for Staging (ICON-S): A multicentre cohort study. Lancet Oncol. 2016, 17, 440-451. [CrossRef]

152. Huang, S.H.; Xu, W.; Waldron, J.; Siu, L.; Shen, X.; Tong, L.; Ringash, J.; Bayley, A.; Kim, J.; Hope, A.; et al. Refining American Joint Committee on Cancer/Union for International Cancer Control TNM stage and prognostic groups for human papillomavirusrelated oropharyngeal carcinomas. J. Clin. Oncol. 2015, 33, 836-845. [CrossRef] [PubMed]

153. O'Sullivan, B.; Huang, S.H.; Siu, L.L.; Waldron, J.; Zhao, H.; Perez-Ordonez, B.; Weinreb, I.; Kim, J.; Ringash, J.; Bayley, A.; et al. Deintensification candidate subgroups in human papillomavirus-related oropharyngeal cancer according to minimal risk of distant metastasis. J. Clin. Oncol. 2013, 31, 543-550. [CrossRef] [PubMed]

154. Huang, S.H.; Perez-Ordonez, B.; Weinreb, I.; Hope, A.; Massey, C.; Waldron, J.N.; Kim, J.; Bayley, A.J.; Cummings, B.; Cho, B.C.; et al. Natural course of distant metastases following radiotherapy or chemoradiotherapy in HPV-related oropharyngeal cancer. Oral Oncol. 2013, 49, 79-85. [CrossRef] [PubMed]

155. Huang, S.H.; Perez-Ordonez, B.; Liu, F.-F.; Waldron, J.; Ringash, J.; Irish, J.; Cummings, B.; Siu, L.L.; Kim, J.; Weinreb, I.; et al. Atypical Clinical Behavior of p16-Confirmed HPV-Related Oropharyngeal Squamous Cell Carcinoma Treated With Radical Radiotherapy. Int. J. Radiat. Oncol. 2012, 82, 276-283. [CrossRef]

156. Trosman, S.J.; Koyfman, S.A.; Ward, M.C.; Al-Khudari, S.; Nwizu, T.; Greskovich, J.F.; Lamarre, E.D.; Scharpf, J.; Khan, M.J.; Lorenz, R.R.; et al. Effect of human papillomavirus on patterns of distant metastatic failure in oropharyngeal squamous cell carcinoma treated with chemoradiotherapy. JAMA Otolaryngol. Head Neck Surg. 2015, 141, 457-462. [CrossRef] 
157. Bishop, J.A.; Ogawa, T.; Chang, X.; Illei, P.B.; Gabrielson, E.; Pai, S.I.; Westra, W.H. HPV analysis in distinguishing second primary tumors from lung metastases in patients with head and neck squamous cell carcinoma. Am. J. Surg. Pathol. 2012, 36, 142-148. [CrossRef]

158. Fakhry, C.; Zhang, Q.; Nguyen-Tan, P.F.; Rosenthal, D.; El-Naggar, A.; Garden, A.S.; Soulieres, D.; Trotti, A.; Avizonis, V.; Ridge, J.A.; et al. Human papillomavirus and overall survival after progression of oropharyngeal squamous cell carcinoma. J. Clin. Oncol. 2014, 32, 3365-3373. [CrossRef]

159. Vermorken, J.B.; Psyrri, A.; Mesía, R.; Peyrade, F.; Beier, F.; de Blas, B.; Celik, I.; Licitra, L. Impact of tumor HPV status on outcome in patients with recurrent and/or metastatic squamous cell carcinoma of the head and neck receiving chemotherapy with or without cetuximab: Retrospective analysis of the phase III EXTREME trial. Ann. Oncol. 2014, 25, 801-807. [CrossRef]

160. Mehra, R.; Seiwert, T.Y.; Gupta, S.; Weiss, J.; Gluck, I.; Eder, J.P.; Burtness, B.; Tahara, M.; Keam, B.; Kang, H.; et al. Efficacy and safety of pembrolizumab in recurrent/metastatic head and neck squamous cell carcinoma: Pooled analyses after long-term follow-up in KEYNOTE-012. Br. J. Cancer 2018, 119, 153-159. [CrossRef]

161. Ferris, R.L.; Blumenschein, G., Jr.; Fayette, J.; Guigay, J.; Colevas, A.D.; Licitra, L.; Harrington, K.J.; Kasper, S.; Vokes, E.E.; Even, C.; et al. Nivolumab vs investigator's choice in recurrent or metastatic squamous cell carcinoma of the head and neck: 2-year long-term survival update of CheckMate 141 with analyses by tumor PD-L1 expression. Oral Oncol. 2018, 81, 45-51. [CrossRef]

162. Ferris, R.L.; Spanos, W.C.; Leidner, R.; Gonçalves, A.; Martens, U.M.; Kyi, C.; Sharfman, W.; Chung, C.H.; Devriese, L.A.; Gauthier, H.; et al. Neoadjuvant nivolumab for patients with resectable HPV-positive and HPV-negative squamous cell carcinomas of the head and neck in the CheckMate 358 trial. J. Immunother. Cancer 2021, 9. [CrossRef]

163. Lyford-Pike, S.; Peng, S.; Young, G.D.; Taube, J.M.; Westra, W.H.; Akpeng, B.; Bruno, T.C.; Richmon, J.D.; Wang, H.; Bishop, J.A.; et al. Evidence for a role of the PD-1:PD-L1 pathway in immune resistance of HPV-associated head and neck squamous cell carcinoma. Cancer Res. 2013, 73, 1733-1741. [CrossRef]

164. Hong, A.M.; Ferguson, P.; Dodds, T.; Jones, D.; Li, M.; Yang, J.; Scolyer, R.A. Significant association of PD-L1 expression with human papillomavirus positivity and its prognostic impact in oropharyngeal cancer. Oral Oncol. 2019, 92, 33-39. [CrossRef]

165. Hong, A.M.; Vilain, R.E.; Romanes, S.; Yang, J.; Smith, E.; Jones, D.; Scolyer, R.A.; Lee, C.S.; Zhang, M.; Rose, B. PD-L1 expression in tonsillar cancer is associated with human papillomavirus positivity and improved survival: Implications for anti-PD1 clinical trials. Oncotarget 2016, 7, 77010-77020. [CrossRef]

166. Jeong, J.Y.; Park, T.I.; Ahn, D. Comprehensive Analysis and Clinical Implication of PD-L1 Expression Considering HPV Status in Oropharyngeal Squamous Cell Carcinoma. Anticancer Res. 2020, 40, 4001-4010. [CrossRef]

167. Wang, J.; Sun, H.; Zeng, Q.; Guo, X.J.; Wang, H.; Liu, H.H.; Dong, Z.Y. HPV-positive status associated with inflamed immune microenvironment and improved response to anti-PD-1 therapy in head and neck squamous cell carcinoma. Sci. Rep. 2019, 9, 13404. [CrossRef]

168. Chureemas, T.; Larbcharoensub, N.; Juengsamarn, J.; Layangkool, T.; Jiarpinitnun, C.; Chansriwong, P.; Trachu, N.; Pattaranutaporn, P.; Ngamphaiboon, N. 978P - Prevalence, pattern, and impact of PD-L1 expression and HPV-status in head and neck squamous cell carcinoma. Ann. Oncol. 2016, 27, vi337. [CrossRef]

169. Patel, J.J.; Levy, D.A.; Nguyen, S.A.; Knochelmann, H.M.; Day, T.A. Impact of PD-L1 expression and human papillomavirus status in anti-PD1/PDL1 immunotherapy for head and neck squamous cell carcinoma-Systematic review and meta-analysis. Head Neck 2020, 42, 774-786. [CrossRef]

170. Gillison, M.L.; Trotti, A.M.; Harris, J.; Eisbruch, A.; Harari, P.M.; Adelstein, D.J.; Jordan, R.C.K.; Zhao, W.; Sturgis, E.M.; Burtness, B.; et al. Radiotherapy plus cetuximab or cisplatin in human papillomavirus-positive oropharyngeal cancer (NRG Oncology RTOG 1016): A randomised, multicentre, non-inferiority trial. Lancet 2019, 393, 40-50. [CrossRef]

171. Mehanna, H.; Robinson, M.; Hartley, A.; Kong, A.; Foran, B.; Fulton-Lieuw, T.; Dalby, M.; Mistry, P.; Sen, M.; O’Toole, L.; et al. Radiotherapy plus cisplatin or cetuximab in low-risk human papillomavirus-positive oropharyngeal cancer (De-ESCALaTE HPV): An open-label randomised controlled phase 3 trial. Lancet 2019, 393, 51-60. [CrossRef]

172. Katada, C.; Hara, H.; Fujii, H.; Nakajima, T.E.; Ando, T.; Nomura, M.; Kojima, T.; Yamashita, K.; Yokoyama, T.; Sakamoto, Y.; et al. A phase II study of chemoselection with docetaxel, cisplatin, and 5-fluorouracil as a strategy for organ preservation in patients with resectable esophageal cancer (CROC trial). J. Clin. Oncol. 2021, 39, 4027-4027. [CrossRef]

173. Nichols, A.C.; Theurer, J.; Prisman, E.; Read, N.; Berthelet, E.; Tran, E.; Fung, K.; de Almeida, J.R.; Bayley, A.; Goldstein, D.P.; et al. Radiotherapy versus transoral robotic surgery and neck dissection for oropharyngeal squamous cell carcinoma (ORATOR): An open-label, phase 2, randomised trial. Lancet Oncol. 2019, 20, 1349-1359. [CrossRef]

174. Ferris, R.L.; Flamand, Y.; Weinstein, G.S.; Li, S.; Quon, H.; Mehra, R.; Garcia, J.J.; Ringash, J.; Lewin, J.S.; Duvvuri, U.; et al. Updated report of a phase II randomized trial of transoral surgical resection followed by low-dose or standard postoperative therapy in resectable p16+ locally advanced oropharynx cancer: A trial of the ECOG-ACRIN cancer research group (E3311). J. Clin. Oncol. 2021, 39, 6010. [CrossRef]

175. Yom, S.S.; Torres-Saavedra, P.; Caudell, J.J.; Waldron, J.N.; Gillison, M.L.; Xia, P.; Truong, M.T.; Kong, C.; Jordan, R.; Subramaniam, R.M.; et al. Reduced-Dose Radiation Therapy for HPV-Associated Oropharyngeal Carcinoma (NRG Oncology HN002). J. Clin. Oncol. 2021, 39, 956-965. [CrossRef]

176. Nguyen-Tan, P.F.; Zhang, Q.; Ang, K.K.; Weber, R.S.; Rosenthal, D.I.; Soulieres, D.; Kim, H.; Silverman, C.; Raben, A.; Galloway, T.J.; et al. Randomized phase III trial to test accelerated versus standard fractionation in combination with concurrent cisplatin for 
head and neck carcinomas in the Radiation Therapy Oncology Group 0129 trial: Long-term report of efficacy and toxicity. J. Clin. Oncol. 2014, 32, 3858-3866. [CrossRef]

177. Ang, K.K.; Zhang, Q.; Rosenthal, D.I.; Nguyen-Tan, P.F.; Sherman, E.J.; Weber, R.S.; Galvin, J.M.; Bonner, J.A.; Harris, J.; El-Naggar, A.K.; et al. Randomized phase III trial of concurrent accelerated radiation plus cisplatin with or without cetuximab for stage III to IV head and neck carcinoma: RTOG 0522. J. Clin. Oncol. 2014, 32, 2940-2950. [CrossRef]

178. Haddad, R.; O’Neill, A.; Rabinowits, G.; Tishler, R.; Khuri, F.; Adkins, D.; Clark, J.; Sarlis, N.; Lorch, J.; Beitler, J.J.; et al. Induction chemotherapy followed by concurrent chemoradiotherapy (sequential chemoradiotherapy) versus concurrent chemoradiotherapy alone in locally advanced head and neck cancer (PARADIGM): A randomised phase 3 trial. Lancet Oncol. 2013, 14, 257-264. [CrossRef]

179. Lee, N.Y.; Ferris, R.L.; Psyrri, A.; Haddad, R.I.; Tahara, M.; Bourhis, J.; Harrington, K.; Chang, P.M.; Lin, J.C.; Razaq, M.A.; et al. Avelumab plus standard-of-care chemoradiotherapy versus chemoradiotherapy alone in patients with locally advanced squamous cell carcinoma of the head and neck: A randomised, double-blind, placebo-controlled, multicentre, phase 3 trial. Lancet Oncol. 2021, 22, 450-462. [CrossRef]

180. Powell, S.F.; Gold, K.A.; Gitau, M.M.; Sumey, C.J.; Lohr, M.M.; McGraw, S.C.; Nowak, R.K.; Jensen, A.W.; Blanchard, M.J.; Fischer, C.D.; et al. Safety and Efficacy of Pembrolizumab With Chemoradiotherapy in Locally Advanced Head and Neck Squamous Cell Carcinoma: A Phase IB Study. J. Clin. Oncol. 2020, 38, 2427-2437. [CrossRef]

181. Leeman, J.E.; Li, J.G.; Pei, X.; Venigalla, P.; Zumsteg, Z.S.; Katsoulakis, E.; Lupovitch, E.; McBride, S.M.; Tsai, C.J.; Boyle, J.O.; et al. Patterns of Treatment Failure and Postrecurrence Outcomes Among Patients With Locally Advanced Head and Neck Squamous Cell Carcinoma After Chemoradiotherapy Using Modern Radiation Techniques. JAMA Oncol. 2017, 3, 1487-1494. [CrossRef]

182. Pignon, J.P.; le Maître, A.; Maillard, E.; Bourhis, J. Meta-analysis of chemotherapy in head and neck cancer (MACH-NC): An update on 93 randomised trials and 17,346 patients. Radiother Oncol. 2009, 92, 4-14. [CrossRef] [PubMed]

183. Wieking, B.G.; Vermeer, D.W.; Spanos, W.C.; Lee, K.M.; Vermeer, P.; Lee, W.T.; Xu, Y.; Gabitzsch, E.S.; Balcaitis, S.; Balint, J.P., Jr.; et al. A non-oncogenic HPV 16 E6/E7 vaccine enhances treatment of HPV expressing tumors. Cancer Gene 2012, 19, 667-674. [CrossRef] [PubMed]

184. Wu, A.; Zeng, Q.; Kang, T.H.; Peng, S.; Roosinovich, E.; Pai, S.I.; Hung, C.F. Innovative DNA vaccine for human papillomavirus (HPV)-associated head and neck cancer. Gene 2011, 18, 304-312. [CrossRef] [PubMed]

185. Smalley Rumfield, C.; Roller, N.; Pellom, S.T.; Schlom, J.; Jochems, C. Therapeutic Vaccines for HPV-Associated Malignancies. Immunotargets 2020, 9, 167-200. [CrossRef]

186. Kirtane, K.; Massarelli, E.; Hanna, G.J.; Klebanoff, C.A.; Blumenschein, G.; Bishop, M.R.; Lee, S.; Niu, J.; Adhikary, S.; Astrow, S.H.; et al. KITE-439: A phase I study of HPV16 E7 T cell receptor-engineered T cells in patients with relapsed/refractory HPV16-positive cancers. J. Clin. Oncol. 2020, 38, TPS3149-TPS3149. [CrossRef]

187. Guo, Y.; Ahn, M.J.; Chan, A.; Wang, C.H.; Kang, J.H.; Kim, S.B.; Bello, M.; Arora, R.S.; Zhang, Q.; He, X.; et al. Afatinib versus methotrexate as second-line treatment in Asian patients with recurrent or metastatic squamous cell carcinoma of the head and neck progressing on or after platinum-based therapy (LUX-Head \& Neck 3): An open-label, randomised phase III trial. Ann. Oncol. 2019, 30, 1831-1839. [CrossRef]

188. Gougis, P.; Moreau Bachelard, C.; Kamal, M.; Gan, H.K.; Borcoman, E.; Torossian, N.; Bièche, I.; Le Tourneau, C. Clinical Development of Molecular Targeted Therapy in Head and Neck Squamous Cell Carcinoma. JNCI Cancer Spectr. 2019, 3, pkz055. [CrossRef]

189. Nichols, A.C.; Palma, D.A.; Chow, W.; Tan, S.; Rajakumar, C.; Rizzo, G.; Fung, K.; Kwan, K.; Wehrli, B.; Winquist, E.; et al. High frequency of activating PIK3CA mutations in human papillomavirus-positive oropharyngeal cancer. JAMA Otolaryngol. Head Neck Surg. 2013, 139, 617-622. [CrossRef]

190. Hoadley, K.A.; Yau, C.; Hinoue, T.; Wolf, D.M.; Lazar, A.J.; Drill, E.; Shen, R.; Taylor, A.M.; Cherniack, A.D.; Thorsson, V.; et al. Cell-ofOrigin Patterns Dominate the Molecular Classification of 10,000 Tumors from 33 Types of Cancer. Cell 2018, 173, 291-304. [CrossRef]

191. Dunn, L.A.; Riaz, N.; Fury, M.G.; McBride, S.M.; Michel, L.; Lee, N.Y.; Sherman, E.J.; Baxi, S.S.; Haque, S.S.; Katabi, N.; et al. A Phase 1b Study of Cetuximab and BYL719 (Alpelisib) Concurrent with Intensity Modulated Radiation Therapy in Stage III-IVB Head and Neck Squamous Cell Carcinoma. Int. J. Radiat. Oncol. Biol. Phys. 2020, 106, 564-570. [CrossRef]

192. Gilardi, M.; Wang, Z.; Proietto, M.; Chillà, A.; Calleja-Valera, J.L.; Goto, Y.; Vanoni, M.; Janes, M.R.; Mikulski, Z.; Gualberto, A.; et al. Tipifarnib as a Precision Therapy for HRAS-Mutant Head and Neck Squamous Cell Carcinomas. Mol. Cancer 2020, 19, 1784-1796. [CrossRef]

193. Adkins, D.; Ley, J.; Neupane, P.; Worden, F.; Sacco, A.G.; Palka, K.; Grilley-Olson, J.E.; Maggiore, R.; Salama, N.N.; Trinkaus, K.; et al. Palbociclib and cetuximab in platinum-resistant and in cetuximab-resistant human papillomavirus-unrelated head and neck cancer: A multicentre, multigroup, phase 2 trial. Lancet Oncol. 2019, 20, 1295-1305. [CrossRef]

194. Moutafi, M.; Economopoulou, P.; Rimm, D.; Psyrri, A. PARP inhibitors in head and neck cancer: Molecular mechanisms, preclinical and clinical data. Oral Oncol. 2021, 117, 105292. [CrossRef]

195. Gold, K.A.; Sacco, A.; Bykowski, J.; Daniels, G.; Pittman, E.; Messer, K.; Chen, R.; Cohen, E. Abstract CT134: A phase I study of avelumab, palbociclib, and cetuximab (APC) in recurrent or metastatic head and neck squamous cell carcinoma (RM HNSCC). Cancer Res. 2021, 81, CT134. [CrossRef]

196. Wang, H.; Wang, B.; Wei, J.; Meng, L.; Zhang, Q.; Qu, C.; Xin, Y.; Jiang, X. Molecular mechanisms underlying increased radiosensitivity in human papillomavirus-associated oropharyngeal squamous cell carcinoma. Int. J. Biol. Sci. 2020, 16, 1035-1043. [CrossRef] 
197. Li, H.; Torabi, S.J.; Yarbrough, W.G.; Mehra, S.; Osborn, H.A.; Judson, B. Association of Human Papillomavirus Status at Head and Neck Carcinoma Subsites With Overall Survival. JAMA Otolaryngol. Head Neck Surg. 2018, 144, 519-525. [CrossRef]

198. Mahal, B.A.; Catalano, P.J.; Haddad, R.I.; Hanna, G.J.; Kass, J.I.; Schoenfeld, J.D.; Tishler, R.B.; Margalit, D.N. Incidence and Demographic Burden of HPV-Associated Oropharyngeal Head and Neck Cancers in the United States. Cancer Epidemiol. Biomark. Prev. 2019, 28, 1660-1667. [CrossRef]

199. Nauta, I.H.; Heideman, D.A.M.; Brink, A.; van der Steen, B.; Bloemena, E.; Koljenović, S.; Baatenburg de Jong, R.J.; Leemans, C.R.; Brakenhoff, R.H. The unveiled reality of human papillomavirus as risk factor for oral cavity squamous cell carcinoma. Int. J. Cancer 2021, 149, 420-430. [CrossRef]

200. Stephen, J.K.; Divine, G.; Chen, K.M.; Chitale, D.; Havard, S.; Worsham, M.J. Significance of p16 in Site-specific HPV Positive and HPV Negative Head and Neck Squamous Cell Carcinoma. Cancer Clin. Oncol. 2013, 2, 51-61. [CrossRef]

201. Vitzthum, L.K.; Mell, L.K. The role of p16 as a biomarker in nonoropharyngeal head and neck cancer. Oncotarget 2018, 9 , 33247-33248. [CrossRef]

202. Takahashi, T.; Ellingson, M.K.; Wong, P.; Israelow, B.; Lucas, C.; Klein, J.; Silva, J.; Mao, T.; Oh, J.E.; Tokuyama, M.; et al. Sex differences in immune responses that underlie COVID-19 disease outcomes. Nature 2020, 588, 315-320. [CrossRef]

203. Windon, M.J.; Waterboer, T.; Hillel, A.T.; Chien, W.; Best, S.; Stewart, C.; Akst, L.; Troy, T.; Bender, N.; Miles, B.; et al. Sex differences in HPV immunity among adults without cancer. Hum. Vaccin. Immunother. 2019, 15, 1935-1941. [CrossRef]

204. Özdemir, B.C.; Dotto, G.P. Sex Hormones and Anticancer Immunity. Clin. Cancer Res. 2019, 25, 4603-4610. [CrossRef]

205. Gubbels Bupp, M.R.; Jorgensen, T.N. Androgen-Induced Immunosuppression. Front. Immunol. 2018, 9, 794. [CrossRef] 